\title{
Evolution of developmental sequences in lepidosaurs
}

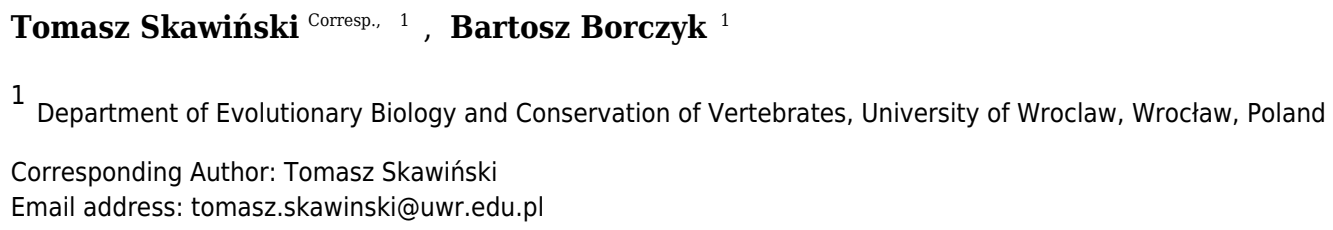

Background. Lepidosaurs, a group including rhynchocephalians and squamates, are one of the major clades of extant vertebrates. Although there has been extensive phylogenetic work on this clade, its interrelationships are a matter of debate. Morphological and molecular data suggest very different relationships within squamates. Despite this, relatively few studies have assessed the utility of other types of data for inferring squamate phylogeny.

Methods. We used developmental sequences of 20 events in 29 species of lepidosaurs. These sequences were analysed using event-pairing and continuous analysis. They were transformed into cladistic characters and analysed in TNT. Ancestral state reconstructions were performed on two main phylogenetic hypotheses of squamates (morphological and molecular).

Results. Cladistic analyses conducted using characters generated by these methods do not resemble any previously published phylogeny. Ancestral state reconstructions are equally consistent with both morphological and molecular hypotheses of squamate phylogeny. Only several inferred heterochronic events are common to all methods and phylogenies.

Discussion. Results of the cladistic analyses, and the fact that reconstructions of heterochronic events show more similarities between certain methods rather than phylogenetic hypotheses, suggest that phylogenetic signal is at best weak in the studied developmental events. Possibly the developmental sequences analysed here evolve too quickly to recover deep divergences within Squamata. 


\section{Evolution of developmental sequences in lepidosaurs}

2 Tomasz Skawiński ${ }^{1}$, Bartosz Borczyk ${ }^{1}$

$3 \quad{ }^{1}$ Department of Evolutionary Biology and Conservation of Vertebrates, University of Wrocław,

4 Wrocław, Poland

5

6 Corresponding Author:

7 Tomasz Skawiński ${ }^{1}$

8 Sienkiewicza 21, Wrocław, PL-50-335, Poland

9 Email address: tomasz.skawinski@uwr.edu.pl 


\begin{abstract}
Background. Lepidosaurs, a group including rhynchocephalians and squamates, are one of the major clades of extant vertebrates. Although there has been extensive phylogenetic work on this clade, its interrelationships are a matter of debate. Morphological and molecular data suggest very different relationships within squamates. Despite this, relatively few studies have assessed the utility of other types of data for inferring squamate phylogeny.
\end{abstract}

Methods. We used developmental sequences of 20 events in 29 species of lepidosaurs. These sequences were analysed using event-pairing and continuous analysis. They were transformed into cladistic characters and analysed in TNT. Ancestral state reconstructions were performed on two main phylogenetic hypotheses of squamates (morphological and molecular).

Results. Cladistic analyses conducted using characters generated by these methods do not resemble any previously published phylogeny. Ancestral state reconstructions are equally consistent with both morphological and molecular hypotheses of squamate phylogeny. Only several inferred heterochronic events are common to all methods and phylogenies.

Discussion. Results of the cladistic analyses, and the fact that reconstructions of heterochronic events show more similarities between certain methods rather than phylogenetic hypotheses, suggest that phylogenetic signal is at best weak in the studied developmental events. Possibly the developmental sequences analysed here evolve too quickly to recover deep divergences within Squamata.

\title{
Introduction
}

With over 10,000 species, Squamata (lizards, snakes and amphisbaenians) are one of the most species-rich extant tetrapod lineages (Uetz, Freed \& Hošek, 2016). However, our understanding of their evolutionary history is confounded by the conflict between phylogenetic hypotheses based on morphology and molecular data (e.g. Losos, Hillis \& Greene, 2012). Morphological analyses suggest that the first divergence within Squamata was between Iguania (iguanas, agamas, chameleons and kin) and Scleroglossa (all other lizards and snakes) (e.g. Estes, de Queiroz \& Gauthier, 1988; Conrad, 2008; Gauthier et al., 2012), while molecular studies indicate that iguanians are highly derived lizards, closely related to anguimorphs (e.g. monitor lizards) and snakes, and that limbless dibamids or gekkotans (geckos and kin, sometimes also including dibamids) are the first-diverging branch of squamates (e.g. Townsend et al. 2004, Vidal \& Hedges, 2005; Wiens et al., 2010, 2012; Pyron, Burbrink \& Wiens, 2013). Increasing the number of taxa and characters in these analyses has not led to an improvement of our understanding of squamate phylogeny, but rather has only increased the discordance between the hypotheses based on those two lines of evidence. Combined morphological and molecular analyses (e.g. Wiens et al., 2010; Reeder et al., 2015) generally favour the molecular topology (but see Lee, 2005). However, some authors argue that molecular data may not be ideal for resolving the higher-level phylogeny of squamates because of the large genetic distance between squamates and their closest living relative - the tuatara (Sphenodon punctatus), the only extant rhynchocephalian - and thus the only reasonable proximal outgroup to Squamata in phylogenetic analyses (McMahan et al., 2015). Despite numerous publications on this subject (Gauthier et al., 2012; Losos, Hillis \& Greene, 2012; Reeder et al., 2015), the debate continues and still new 
52 approaches to the problem are being taken (McMahan et al., 2015; Harrington, Leavitt \& Reeder, 53 2016; Pyron, 2017).

54 Developmental data may be useful for phylogenetic inference (e.g. Laurin \& Germain, 2011) but

55

56

57

58

59

60

61

62

63

64

65

66

67

68

69

70

71

72

73

74

75

76

77

78

79

80

81

82

83

84

85

86

87

88

89

90

91

92

93

they rarely have been used in squamate phylogenetics. Notable exceptions are the studies of Maisano (2002) and Werneburg \& Sánchez-Villagra (2015), using ossification sequences. The former found that these sequences are useful for determininig relatively shallow divergences but failed to recover deeper nodes, possibly because of their high rate of evolution (Maisano, 2002). Werneburg \& Sánchez-Villagra (2015) found that developmental data were most congruent with the close relationship between snakes and varanids, as postulated by some morphological studies (e.g. Lee, 1997) but also some combined morphological and molecular analyses (e.g. Lee, 2005). Sequences of other developmental traits were studied by Andrews, Brandley \& Greene (2013) but the authors regarded relationships of squamates as "well defined" and reconstructed the ancestral states only on the molecular topologies. Moreover, their study did not consider the tuatara, a taxon critical in studying lepidosaur evolution. We attempt to supplement their data with the developmental sequence of the tuatara and reconstruct ancestral states using both molecular and morphological topologies. We also assess phylogenetic utility of timing of organogenesis using several different methods.

\section{Materials \& Methods}

Character construction and cladistic analyses. Developmental sequences of 20 characters in 21 species representing most major squamate lineages (Tables 1-2) were obtained from Andrews, Brandley \& Greene (2013). Developmental sequences of seven other squamate species were taken from the literature (Table 1). The developmental sequence of the tuatara was compiled from Dendy (1899) and Sanger, Gredler \& Cohn (2015) (see also Moffat, 1985). These sequences were transformed into continuous characters, where the first event has a value of 0 , and the last one - a value of 1 (Germain \& Laurin, 2009; Laurin \& Germain, 2011). These values constituted the basis for cladistic characters, which were created following Werneburg \& Sánchez-Villagra (2015) - values between 0 and 0.09 were coded as 0 , between 0.1 and 0.19 were coded as 1 , and so on. The missing data were coded as unknown (?), while limb characters in snakes were coded as inapplicable (-). Cladistic analyses employing these characters were conducted in TNT v. 1.1 (Goloboff, Farris \& Nixon, 2003, 2008), using the traditional search option, with 10 replications of Wagner trees. These trees were held in RAM and subjected to tree bisection reconnection, holding 10 trees per replicate. In the first analysis, all characters were unordered (non-additive), and in the second one, all were ordered (additive) (see Werneburg \& Sánchez-Villagra, 2009; Laurin \& Germain, 2011). In both analyses, Sphenodon was used as the outgroup.

Another set of cladistic characters was created using the event-pairing method (Smith, 1997; Velhagen, 1997; Jeffery et al., 2002a, 2005). Comparing 20 developmental events in 29 species resulted in 190 event pairs. These characters were analysed in the same way as continuous characters.

With these cladistic characters and files with both molecular and morphological topology in memory, Templeton test (Templeton, 1983) was performed in TNT (using a script written by 
Alexander Schmidt-Lebuhn, https://www.anbg.gov.au/cpbr/tools/templetontest.tnt). Four replications were conducted: using either ordered or unordered characters; and employing continuous or event-paired characters.

Ancestral state reconstruction and heterochronic events. Reconstruction of ancestral states was performed in Mesquite v. 3.2 (Maddison \& Maddison, 2017). Developmental sequences were mapped on two competing phylogenetic hypotheses of lepidosaurs - first one, from Pyron, Burbrink \& Wiens (2013), using seven nuclear and five mitochondrial genes, and the second one, from Gauthier et al. (2012), the largest morphological analysis to date. Ancestral states were reconstructed using both maximum parsimony and maximum likelihood for event-paired data and square-changed parsimony for continuous data. The branch length may have a significant effect on reconstruction of ancestral states (e.g. Andrews, Brandley \& Greene, 2013; Boyd, 2015), so analyses using maximum likelihood and square-changed parsimony were performed on both molecular and morphological topologies. In the first analysis, all branches were given an equal length $(=1)$, while in the second, the branch lengths were calibrated to reflect the fossil record of a given group. The oldest-known fossil of a total group was used to calibrate the tree rather than that of a crown group (Table 3 ). Only fossils unquestionably placed within a given group were included. When the fossil record of a group was unknown (mostly in relatively recently diverged species), the branch length was set, arbitrarily, as 3. Square-changed parsimony reconstruction using continuous data was performed using root node reconstruction in PDAP:PDTREE module of Mesquite (Midford, Garland \& Maddison, 2011). This module calculates 95\% confidence intervals (Garland \& Ives, 2000) for each character of a hypothetical ancestor of all taxa included in a tree (in this case, ancestral lepidosaur). A statistically significant heterochronic event occurs when a value of character state of a given taxon is beyond the confidence interval. In the second analysis, Sphenodon was pruned from the tree, and reconstruction was made for the ancestral squamate and compared to the values of terminal taxa.

Event-pair synapomorphies were mapped on both topologies using synapomorphy mapping in TNT. These synapomorphies were subjected to event-pair cracking, following the procedure described in detail by Jeffery et al. (2002a). Only deviations from their methods are described below. Clades supported by only one event-pair synapomorphy, two synapomorphies involving four different events and so on were excluded because the number of developmental changes was insufficient for determining the background pattern and heterochronies. In the ordered dataset, when degree of change was ambiguous (e.g. from 0 to 1 or 2), a mean was taken (in this example, 1.5). Characters in which the direction of change could not be unambiguously reconstructed (i.e. from 1 to 0 or 2) were excluded from further analysis. This should not have significant effect on the analysis, as there was only a few such characters (Tables S1-S8). Only events with total relative change (TRC) beyond the $95 \%$ confidence interval calculated for the mean TRCs at a given node were regarded as heterochronic. This is more a conservative approach than the one taken by Jeffery et al. (2002a) but will make the analysis more comparable to the continuous analysis described above. 
135

136

137

138

139

140

141

142

143

144

145

146

147

148

149

150

151

152

153

154

155

156

157

158

159

160

161

162

163

164

165

166

167

168

169

170

171

172

173

174

175
Cladistic analyses. Cladistic analyses conducted using the transformed continuous data generated trees that are not similar to trees obtained in either morphological or molecular analyses. Analysis using unordered characters yielded 214 most parsimonious trees (MPT; tree length $=109$, consistency index $=0.560$, retention index $=0.628)$, the strict consensus tree of which is almost completely unresolved. This analysis failed to recover clades of very closely related species such as Liolaemus (Fig. 1A). When all characters were ordered, it resulted in 174 most parsimonious trees $(\mathrm{TL}=133, \mathrm{CI}=0.459, \mathrm{RI}=0.625)$. The strict consensus tree is mostly unresolved - the only groups that were monophyletic in all MPTs are Liolaemus, Tropidurus + Strophurus, Calyptommatus + Anolis and a clade including Uta, Agama, Furcifer, Mabuya, Gehyra, Chamaeleo and Zootoca. A 50\% majority rule tree does not resemble published morphological or molecular phylogenies (Fig. 1B).

Similar to the continuous dataset, the event-paired data did not result in a topology matching any previously published phylogeny. Analysis of unordered characters generated 10 MPTs (TL $=$ $185, \mathrm{CI}=0.530, \mathrm{RI}=0.552$ ). In the strict consensus tree Furcifer and Varanus indicus are in trichotomy with the clade including all other squamates. This clade is divided into a group containing seven species of iguanians, gekkotan Strophurus, snake Thamnophis, scincoid Mabuya and lacertiform Zootoca, and the second group to which all other squamates belong (Fig. 2A). Analysis using ordered characters yielded $16 \mathrm{MPTs}(\mathrm{TL}=220, \mathrm{CI}=0.464, \mathrm{RI}=$ 0.599). The strict consensus tree is poorly resolved but excluding Varanus indicus from it significantly improves resolution. After this, squamates are divided into two clades - the first one includes eight species of iguanians, Thamnophis and Mabuya, while the second group includes all other squamates (Fig. 2B).

Mapping of continuous characters indicates slight differences in tree length between morphological and molecular topologies. With all branches being assigned equal length $(=1)$, the former is 1.49630768 steps long and the latter -1.51610078 . With the fossil-calibrated tree, the morphological topology is 0.19257679 steps long and molecular -0.17638729 . Mapping of unordered event-paired characters gives the molecular topology a length of 250 steps and the morphological - 252 steps. With ordered characters, the molecular topology is 322 steps long, while the morphological is 327 steps long.

Neither replication of the Templeton test detected any statistically significant differences between morphological and molecular phylogenies under both present continuous and eventpaired character datasets $(\mathrm{p}>0.05$ in all cases $)$.

Developmental diagnoses. There are several event-pair synapomorphies diagnosing some higher-level taxa (i.e. family-level clades or higher). However, at least some of these groups are represented by only a few members (e.g. Anguimorpha, Scincoidea), so these apomorphies may in fact diagnose less inclusive clades (Table 4).

Heterochronic events. Inferred heterochronic events show more consistency between given methods than between phylogenies (e.g. event-paired data for morphological phylogeny are more similar to event-paired data for molecular topology than to continuous data for morphological tree). Only a few of these events are common to all methods and phylogenies (Figs. 3-14). 
176

177

178

179

180

181

182

183

184

185

186

187

188

189

190

191

192

193

194

195

196

197

198

199

200

201

202

203

204

205

206

207

208

209

210

211

212

213

214

215

216

217

\section{Discussion}

Developmental cladistic characters failed to recover topology similar to those based on other data (i.e. molecular or morphological). This was also found in similar studies (Maisano, 2002; Werneburg \& Sánchez-Villagra, 2009, 2015). This may be a consequence of uneven sampling of different squamate clades in the present analysis - out of 28 included species, 11 are iguanians and six are gekkotans, while there are only three anguimorphs (and all of them belong to a single clade, Varanus) and one scincoid. Members of other important clades, like Amphisbaenia and Dibamidae, were not included. Some of these groups only recently were studied in terms of development (e.g. Gregorovicova et al., 2012). Moreover, development of lepidosaurs included in this analysis is incompletely known. Thorough study of developmental sequences of these and other members of these diverse clades will be beneficial to future analyses. However, it may be that homoplasies are very common in developmental sequences of squamates. Moreover, the phylogenetic signal in organogenetic events (at least those used in this study) may be weak or detectable only in deeper nodes of the phylogenetic tree (cf. Jeffery et al., 2002b; Maisano, 2002). This may be indicated by higher congruence between methods in reconstructing heterochronic events than between given phylogenies.

The only cladistic analyses that slightly resembled published phylogenies employed event-paired characters, especially ordered ones (Fig. 1B). In this analysis, eight of eleven included iguanian species formed a monophyletic group with Thamnophis and Mabuya that was sister to all other squamates. This resembles the morphological topology, where iguanians are sister group to all other squamates (e.g. Estes, de Queiroz \& Gauthier, 1988; Conrad, 2008; Gauthier et al., 2012). This may suggest that developmental sequences of most iguanians and the tuatara are relatively similar. Under morphological topology, these similarities would represent symplesiomorphies but under molecular one, would be considered homoplasies. Reeder et al. (2015) suggested that support for basal placement of Iguania comes from the cranial characters. This is not the case in the present analysis. Character mapping and ancestral states reconstructions of event-paired data suggest that potential symplesiomorphies between the tuatara and iguanians (as a whole or one of their major subgroups - Acrodonta and Pleurodonta) are connected with the relatively later torsion completion, rather than of some events concerning head development. Other groups recognized by morphological analyses also receive some support. For example, Scleroglossa are supported by earlier occurrence of torsion completion (simultaneous with occurrence of hyomandibular slit and allantois bud), unlike in tuatara and Iguania. Scincomorpha are supported by simultaneous development of otic placode, allantois bud and secondary optic vesicle.

Gekkotans differ from other squamates in later development of the allantois (Andrews, Brandley \& Green, 2013) but in that trait they resemble the tuatara. Under molecular topology, earlier development of the allantois bud supports the Unidentata (Table 4). This may represent a genuine signal of monophyly of that group, however, caution is warranted. Gekkotans display many paedomorphic features, including their morphology (e.g. Daza, Bauer \& Snively, 2014) and development (Jonasson, Russel \& Vickaryous, 2012). Thus, the condition in gekkotans may represent reversal to the primitive condition (presumably, as displayed by the tuatara) rather than plesiomorphy. This situation is similar to the development of a single egg tooth, which purportedly supports the monophyly of Unidentata (see discussion in Assis \& Rieppel, 2011). To 
218

219

220

221

222

223

224

225

226

227

228

229

230

231

232

233

234

235

236

237

238

239

240

241

242

243

244

245

246

247

248

249

250

251

252

253

254

255

gain more insight into that matter, it would be crucial to sample development of dibamids, the only other non-unidentate squamates.

In the fossil time-calibrated continuous analysis, only one event in two species is inferred to show heterochrony in relation to the ancestral lepidosaur. This may seem surprising, as some squamates show heterochrony to the ancestral squamate (much closer phylogenetically). However, if all studied taxa are extant (as is the case in the present analysis), the long branches would result in wider confidence intervals and thus ancestral state reconstructions for deep nodes of the phylogenetic tree would be less certain (Germain \& Laurin, 2009). Integration of data from fossils would be useful in that regard but it seems highly unlikely that information on organogenesis can be preserved in the fossil record, despite recent significant advances in developmental palaeobiology (e.g. Skawiński \& Tałanda, 2015).

In the continuous analyses (both calibrated and uncalibrated and using either molecular or morphological topology), values of all developmental events of the tuatara are located within the confidence interval of the ancestral squamate. This suggests that present data are equally consistent with either hypothesis of squamate phylogeny (cf. Germain \& Laurin, 2009).

In this study only two major phylogenetic hypotheses of squamates were used. It is not beyond imagination that neither of these phylogenies is fully correct. For example, in the analysis combining morphological and molecular data conducted by Lee (2005) the "fossorial group" is polyphyletic, as suggested by molecular analyses (e.g. Wiens et al., 2012; Pyron, Burbrink \& Wiens, 2013), but division of squamates into Iguania and Scleroglossa is retained, as in morphological analyses (e.g. Conrad, 2008; Gauthier et al., 2012). This could, to some extent, explain the discrepancies in reconstructions of heterochronic events, as none of these would be done on the basis of the correct tree.

\section{Conclusions}

Cladistic analyses conducted using characters generated by event-pairing and continuous analysis do not resemble any previously published phylogeny. Ancestral state reconstructions are equally consistent with both morphological and molecular hypotheses of squamate phylogeny. Results of the cladistic analyses, and the fact that reconstructions of heterochronic events show more similarities between certain methods than phylogenetic hypotheses, suggest that phylogenetic signal is at best weak in the studied developmental events.

\section{Acknowledgements}

We acknowledge The Willi Hennig Society for making TNT freely available. Detailed and constructive comments made by Jessica A. Maisano and an anonymous referee greatly improved the manuscript. We thank John R. Hutchinson for editing.

\section{References}


256 Andrews RM, Brandley MC, Greene VW. 2013. Developmental sequences of squamate reptiles

257 are taxon specific. Evolution \& Development 15:326-343. DOI: 10.1111/ede.12042.

258 Assis LCS, Rieppel O. 2011. Are monophyly and synapomorphy the same or different?

259 Revisiting the role of morphology in phylogenetics. Cladistics 27:94-102. DOI: 10.1111/j.1096-

260 0031.2010.00317.x.

261 Boback SM, Dichter EK, Mistry HL. 2012. A developmental staging series for the African house snake, Boaedon (Lamprophis) fuliginosus. Zoology 115:38-46. DOI: 10.1016/j.zool.2011.09.001.

Bolet A, Evans SE. 2014. Fossil history of chameleons. In: Tolley KA, Herrel A, eds. The biology of chameleons. Berkeley, Los Angeles, London: University of California Press, 175-192. URL: http://www.jstor.org/stable/10.1525/j.ctt5hjj1m.

Boughner JC, Buchtová M, Fu K, Diewert V, Halgrímsson B, Richman JM. 2007. Embryonic development of Python sebae - I: Staging criteria and macroscopic skeletal morphogenesis of the head and limbs. Zoology 110:212-230. DOI: 10.1016/j.zool.2007.01.005.

Boyd CA. 2015. The systematic relationships and biogeographic history of ornithischian dinosaurs. PeerJ 3:e1523. DOI: 10.7717/peerj.1523. Middle Jurassic-Lower Cretaceous provide insights on snake evolution. Nature Communications 6:5996. DOI: 10.1038/ncomms6996.

Conrad JL. 2008. Phylogeny and systematics of Squamata (Reptilia) based on morphology. Bulletin of the American Museum of Natural History 310:1-182. DOI: 10.1206/310.1.

Conrad JL, Rieppel O, Grande L. 2007. A Green River (Eocene) polychrotid (Squamata: DOI: 10.1666/06-005R.1.

280 Daza JD, Bauer AM, Snively EE. 2014. On the fossil record of the Gekkota. Anatomical Record 297:433-462. DOI: 10.1002/ar.22856.

Daza JD, Stanley EL, Wagner P, Bauer AM, Grimaldi DA. 2016. Mid-Cretaceous amber fossils illuminate the past diversity of tropical lizards. Science Advances 2:e1501080. DOI: 10.1126/sciadv.1501080.

Dendy A. 1899. Outlines of the development of the tuatara, Sphenodon (Hatteria) punctatus. Quarterly Journal of Microscopical Science s-42:1-87.

Estes R, de Queiroz K, Gauthier JA. 1988. Phylogenetic relationships within Squamata. In: Estes

290 Evans SE, Chure DJ. 1998. Paramacellodid lizard skulls from the Jurassic Morrison Formation at 291 Dinosaur National Monument, Utah. Journal of Vertebrate Paleontology 18:99-114. DOI:

$29210.1080 / 02724634.1998 .10011037$. 
293 Evans SE, Prasad GVR, Manhas BK. 2002. Fossil lizards from the Jurassic Kota Formation of 294 India. Journal of Vertebrate Paleontology 22:299-312. DOI: 10.1671/0272-

295 4634(2002)022[0299:FLFTJK]2.0.CO;2.

296 Ezcurra MD. 2016. The phylogenetic relationships of basal archosauromorphs, with an emphasis 297 on the systematics of proterosuchian archosauriforms. PeerJ 4:e1778. DOI: 10.7717/peerj.1778.

298 Ezcurra MD, Scheyer TM, Butler RJ. 2014. The origin and early evolution of Sauria: reassessing 299 the Permian saurian fossil record and the timing of the crocodile-lizard divergence. PLOS ONE 300 9:e89165. DOI: 10.1371/journal.pone.0089165.

301 Garland T Jr, Ives AR. 2000. Using the past to predict the present: confidence intervals for 302 regression equations in phylogenetic comparative methods. American Naturalist 155:346-364. 303 DOI: 10.1086/303327.

304 Gauthier JA, Kearney M, Maisano JA, Rieppel O, Behlke ADB. 2012. Assembling the squamate tree of life: perspectives from the phenotype and the fossil record. Bulletin of the Peabody Museum of Natural History 53:3-308. DOI: 10.3374/014.053.0101.

Germain D, Laurin M. 2009. Evolution of ossification sequences in salamanders and urodele origins assessed through event-pairing and new methods. Evolution \& Development 11:170-190. DOI: $10.1111 /$ j.1525-142X.2009.00318.x.

310 Goloboff P, Farris J, Nixon K. 2003. T.N.T.: Tree Analysis Using New Technologies. Available at http://www.lillo.org.ar/phylogeny/tnt/ (accessed 26 February 2017).

312 Goloboff PA, Farris JS, Nixon KC. 2008. TNT, a free program for phylogenetic analysis. 313 Cladistics 24:774-786. DOI: 10.1111/j.1096-0031.2008.00217.x.

314 Gregorovicova M, Zahradnicek O, Tucker AS, Velensky P, Horacek I. 2012. Embryonic 315 development of the monitor lizard, Varanus indicus. Amphibia-Reptilia 33:451-468. DOI: $31610.1163 / 15685381-00002849$.

317 Harrington SM, Leavitt DH, Reeder TW. 2016. Squamate phylogenetics, molecular branch 318 lengths, and molecular apomorphies: a response to McMahan et al. Copeia 104:702-707. DOI: 319 10.1643/CG-16-391.

320 Head JJ. 2015. Fossil calibration dates for molecular phylogenetic analysis of snakes 1:

321 Serpentes, Alethinophidia, Boidae, Pythonidae. Palaeontologia Electronica 18:6FC;1-17.

322 Head JJ, Mahlow K, Müller J. 2016. Fossil calibration dates for molecular phylogenetic analysis

323 of snakes 2: Caenophidia, Colubroidea, Elapoidea, Colubridae. Palaeontologia Electronica 324 19:2FC;1-21.

325 Jeffery JE, Richardson MK, Coates MI, Bininda-Emonds ORP. 2002a. Analyzing developmental 326 sequences within a phylogenetic framework. Systematic Biology 51:478-491. DOI:

$32710.1080 / 10635150290069904$. 
328

329

330

331

332

333

334

335

336

337

338

339

340

341

342

343

344

345

346

347

348

349

350

351

352

353

354

355

356

357

358

359

360

361

362

363

364

Jeffery JE, Bininda-Emonds ORP, Coates MI, Richardson MK. 2002b. Analyzing evolutionary patterns in amniote embryonic development. Evolution \& Development 4:292-302. DOI: 10.1046/j.1525-142X.2002.02018.x.

Jeffery JE, Bininda-Emonds ORP, Coates MI, Richardson MK. 2005. A new technique for identifying sequence heterochrony. Systematic Biology 54:230-240. DOI: $10.1080 / 10635150590923227$.

Jonasson KA, Russell AP, Vickaryous MK. 2012. Histology and histochemistry of the gekkotan notochord and their bearing on the development of notochordal cartilage. Journal of Morphology 273:596-603. DOI: 10.1002/jmor.20004.

Jones MEH, Anderson CL, Hipsley CA, Müller J, Evans SE, Schoch RR. 2013. Integration of molecules and new fossils supports a Triassic origin for Lepidosauria (lizards, snakes, and tuatara). BMC Evolutionary Biology 13:208. DOI: 10.1186/1471-2148-13-208.

Khannoon ER. 2015. Developmental stages of the climbing gecko Tarentola annularis with special reference to the claws, pad lamellae, and subdigital setae. Journal of Experimental Zoology Part B: Molecular and Developmental Evolution 324B:450-464. DOI: 10.1002/jez.b.22630.

Laurin M, Germain D. 2011. Developmental characters in phylogenetic inference and their absolute timing information. Systematic Biology 60:630-644. DOI: 10.1093/sysbio/syr024.

Lee MSY. 1997. The phylogeny of varanoid lizards and the affinities of snakes. Philosophical Transactions of the Royal Society B 352:53-91. DOI: 10.1098/rstb.1998.0005.

Lee MSY. 2005. Molecular evidence and marine snake origins. Biology Letters 1:227-230. DOI: 10.1098/rsbl.2004.0282.

Lima FC. 2015. Ontogenia de Iguana iguana (Linnaeus, 1758): estágios embrionários e desenvolvimento de esqueleto. D. Phil. Thesis, Universidade de Brasília.

Losos JB, Hillis DM, Greene HW. 2012. Who speaks with a forked tongue? Science 338:14281429. DOI: $10.1126 /$ science. 1232455.

Maddison WP, Maddison DR. 2017. Mesquite: a modular system for evolutionary analysis. 3.2. Available at http://mesquiteproject.org and https://mesquiteproject.wikispaces.com (accessed 26 February 2017).

Maisano JA. 2002. The potential utility of postnatal skeletal developmental patterns in squamate phylogenetics. Zoological Journal of the Linnean Society 136:277-313. DOI: 10.1046/j.10963642.2002.00033.x.

McMahan CD, Freeborn LR, Wheeler WC, Crother BI. 2015. Forked tongues revisited: molecular apomorphies support morphological hypotheses of squamate evolution. Copeia 103:525-529. DOI: 10.1643/CH-14-015.

Midford PE, Garland T Jr, Maddison WP. 2011. PDAP:PDTREE package for Mesquite. 1.15. Available at http://mesquiteproject.org/pdap_mesquite/(accessed 26 February 2017). 
365

366

367

368

369

370

371

372

373

374

375

376

377

378

379

380

381

382

383

384

385

386

387

388

389

390

391

392

393

394

395

396

397

398

399

400

401

402

Moffat LA. 1985. Embryonic development and aspects of reproductive biology in the tuatara, Sphenodon punctatus. In: Gans C, Billett F, Maderson PFA, eds. Biology of the Reptilia. Volume 14. Development A. New York, Chichester, Brisbane, Toronto, Singapore: John Wiley \& Sons, 493-522.

Nydam RL. 2013. Squamates from the Jurassic and Cretaceous of North America.

Palaeobiodiversity and Palaeoenvironments 93:535-565. DOI: 10.1007/s12549-013-0129-5.

Nydam RL, Caldwell MW. 2015. A review of the fossil record of teiioid and teiioid-like fossil lizards from the Mesozoic of Laurasia and Gondwana. Programa VCLAPV: 7.

Py-Daniel TR, Soares De-Lima AK, Lima FC, Pic-Taylor A, Pires Junior OR, Sebben A. 2017. A staging table of post-ovipositional development for the South American collared lizard Tropidurus torquatus (Squamata: Tropiduridae). Anatomical Record 300:277-290. DOI: 10.1002/ar.23500.

Pyron RA. 2017. Novel approaches for phylogenetic inference from morphological data and total-evidence dating in squamate reptiles (lizards, snakes, and amphisbaenians). Systematic Biology 66:38-56. DOI: 10.1093/sysbio/syw068.

Pyron RA, Burbrink FT, Wiens JJ. 2013. A phylogeny and revised classification of Squamata, including 4161 species of lizards and snakes. BMC Evolutionary Biology 13:93. DOI: 10.1186/1471-2148-13-93.

Reeder TW, Townsend TM, Mulcahy DG, Noonan BP, Wood PL Jr, Sites JW Jr, Wiens JJ. 2015. Integrated analyses resolve conflicts over squamate phylogeny and reveal unexpected placements for fossil taxa. PLOS ONE 10:e0118199. DOI: 10.1371/journal.pone.0118199.

Sanger TJ, Gredler ML, Cohn MJ. 2015. Resurrecting embryos of the tuatara, Sphenodon punctatus, to resolve vertebrate phallus evolution. Biology Letters 11:20150694. DOI: 10.1098/rsbl.2015.0694.

Sherratt E, Castañeda MdR, Garwood RJ, Mahler LD, Sanger TJ, Herrel A, de Queiroz K, Losos JB. 2015. Amber fossils demonstrate deep-time stability of Caribbean lizard communities.

Proceedings of the National Academy of Sciences 112:9961-9966. DOI: $10.1073 /$ pnas. 1506516112 .

Skawiński T, Tałanda M. 2015 [2014]. Integrating developmental biology and the fossil record of reptiles. International Journal of Developmental Biology 58:949-959. DOI: 10.1387/ijdb.140322mt.

Smith KK. 1997. Comparative patterns of craniofacial development in eutherian and metatherian mammals. Evolution 51:1663-1678. DOI: 10.2307/2411218.

Tałanda M. 2016. Early evolution of lizards in the fossil record. D. Phil. Thesis, University of Warsaw.

Templeton AR. 1983. Phylogenetic inference from restriction endonuclease cleavage site maps with particular reference to the evolution of humans and the apes. Evolution 37:221-244. DOI: $10.2307 / 2408332$. 
403

404

405

406

407

408

409

410

411

412

413

414

415

416

417

418

419

420

421

422

423

424

425

426

427

428

429

430

431

432

Townsend TM, Larson A, Louis E, Macey RJ. 2004. Molecular phylogenetics of Squamata: the position of snakes, amphisbaenians, and dibamids, and the root of the squamate tree. Systematic Biology 53:735-757. DOI: 10.1080/10635150490522340.

Uetz P, Freed P, Hošek J, eds. 2016. The Reptile Database. Available at http://reptiledatabase.org and http://reptile-database.reptarium.cz (accessed 26 February 2017).

Velhagen WA Jr. 1997. Analyzing developmental sequences using sequence units. Systematic Biology 46:204-210. DOI: 10.1093/sysbio/46.1.204.

Venczel M, Codrea VA. 2016. A new teiid lizard from the Late Cretaceous of the Haţeg Basin, Romania and its phylogenetic and palaeobiogeographical relationships. Journal of Systematic Palaeontology 14:219-237. DOI: 10.1080/14772019.2015.1025869.

Vidal N, Hedges SB. 2005. The phylogeny of squamate reptiles (lizards, snakes, and amphisbaenians) inferred from nine nuclear protein-coding genes. Comptes Rendus Biologies 328:1000-1008. DOI: 10.1016/j.crvi.2005.10.001.

Werneburg I, Sánchez-Villagra MR. 2009. Timing of organogenesis support basal position of turtles in amniote tree of life. BMC Evolutionary Biology 9:82. DOI: 10.1186/1471-2148-9-82.

Werneburg I, Sánchez-Villagra MR. 2015. Skeletal heterochrony is associated with the anatomical specializations of snakes among squamate reptiles. Evolution 69:254-263. DOI: 10.1111/evo.12559.

Werneburg I, Polachowski KM, Hutchinson MN. 2015. Bony skull development in the Argus monitor (Squamata, Varanidae, Varanus panoptes) with comments on developmental timing and adult anatomy. Zoology 118:255-280. DOI: 10.1016/j.zool.2015.02.004.

Wiens JJ, Kuczynski CA, Townsend T, Reeder TW, Mulcahy DG, Sites JW Jr. 2010. Combining phylogenomics and fossils in higher-level squamate reptile phylogeny: molecular data change the placement of fossil taxa. Systematic Biology 59:674-688. DOI: 10.1093/sysbio/syq048.

Wiens JJ, Hutter CR, Mulcahy DG, Noonan BP, Townsend TM, Sites JW Jr, Reeder TW. 2012. Resolving the phylogeny of lizards and snakes (Squamata) with extensive sampling of genes and species. Biology Letters 8:1043-1046. DOI: 10.1098/rsbl.2012.0703.

Wise PAD, Vickaryous MK, Russell AP. 2009. An embryonic staging table for in ovo development of Eublepharis macularius, the leopard gecko. Anatomical Record 292:1198-1212. DOI: 10.1002/ar.20945. 


\section{Figure 1}

Results of the cladistic analysis using characters from the continuous analysis.

Strict consensus tree. (A) Unordered characters; $\mathrm{TL}=109, \mathrm{Cl}=0.560, \mathrm{RI}=0.628$. (B)

Ordered characters; $\mathrm{TL}=133, \mathrm{Cl}=0.459, \mathrm{RI}=0.625$. Colour represents clade to which given species belongs.
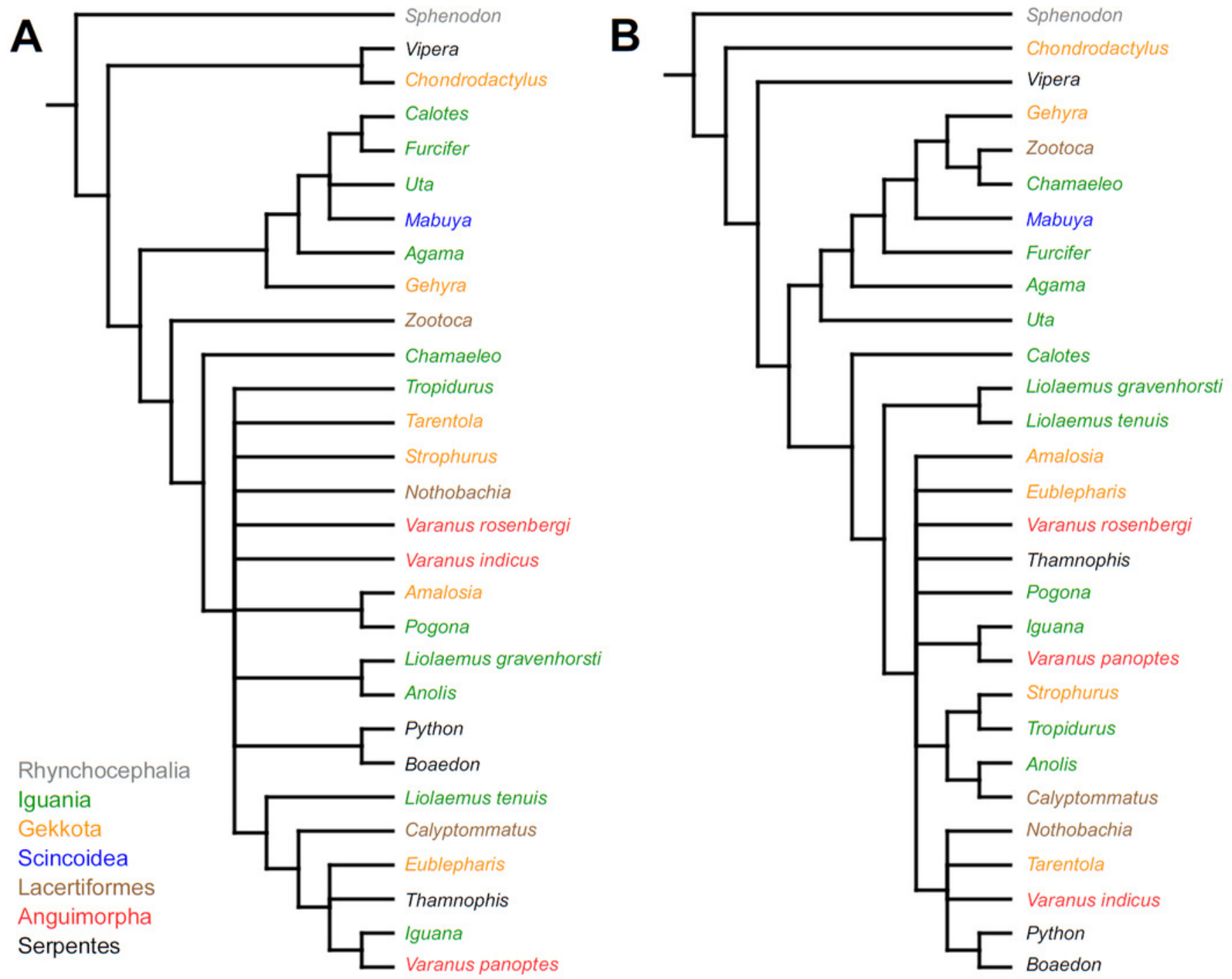


\section{Figure 2}

Results of the cladistic analysis using characters from event-pairing.

Strict consensus tree (in B after excluding Varanus indicus). (A) Unordered characters; $T L=$ $185, \mathrm{Cl}=0.530, \mathrm{RI}=0.552$. (B) Ordered characters; $\mathrm{TL}=220, \mathrm{Cl}=0.464, \mathrm{RI}=0.559$. Colour represents clade to which given species belongs.
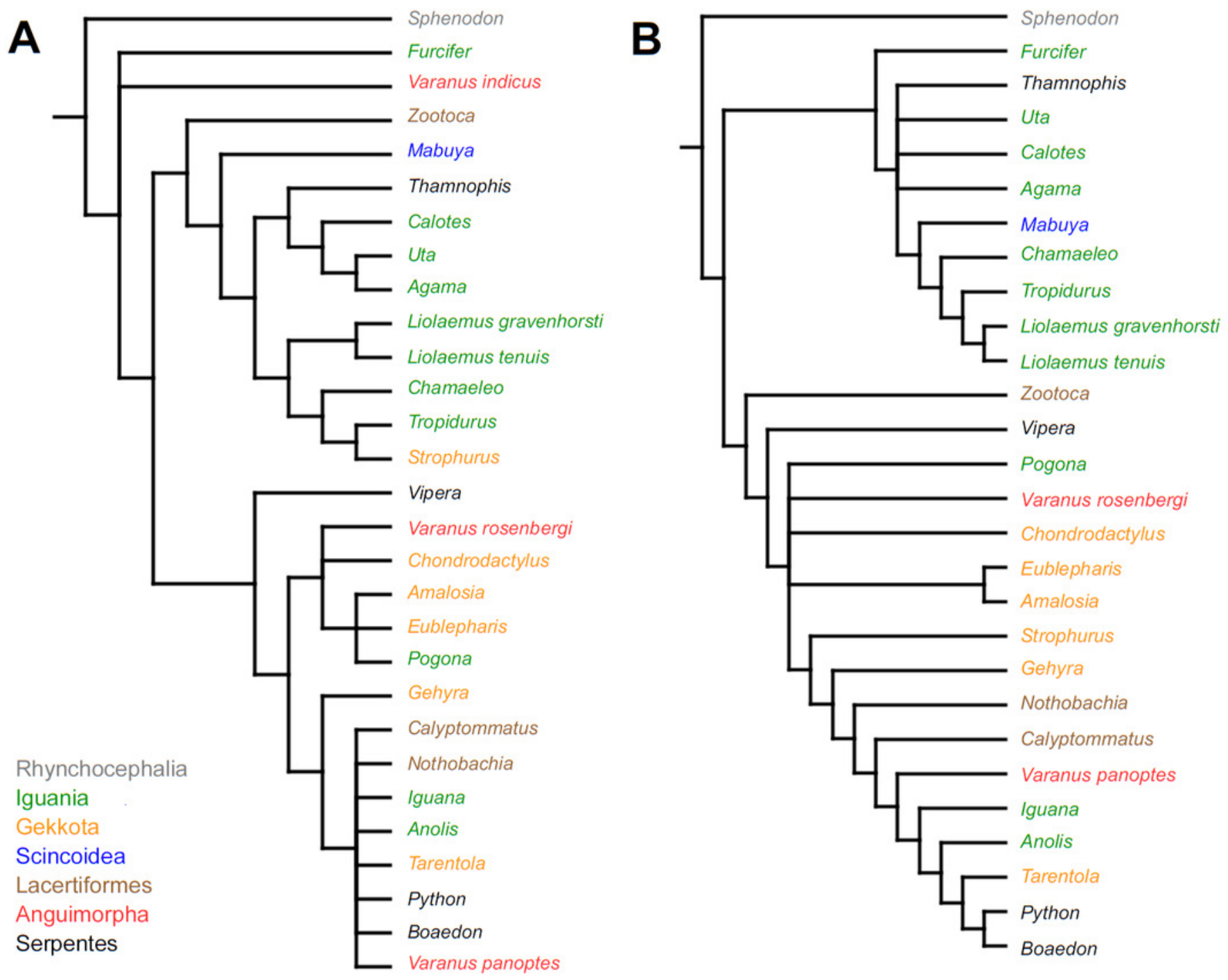
Figure 3

Heterochronic events in lepidosaur evolution.

Mapped onto molecular phylogeny, using continuous data, in relation to the ancestral lepidosaur. Length of all branches equals 1. Numbers within boxes refer to developmental events (Table 2). Down arrow denotes earlier development of a given structure, while up arrow represents later development.

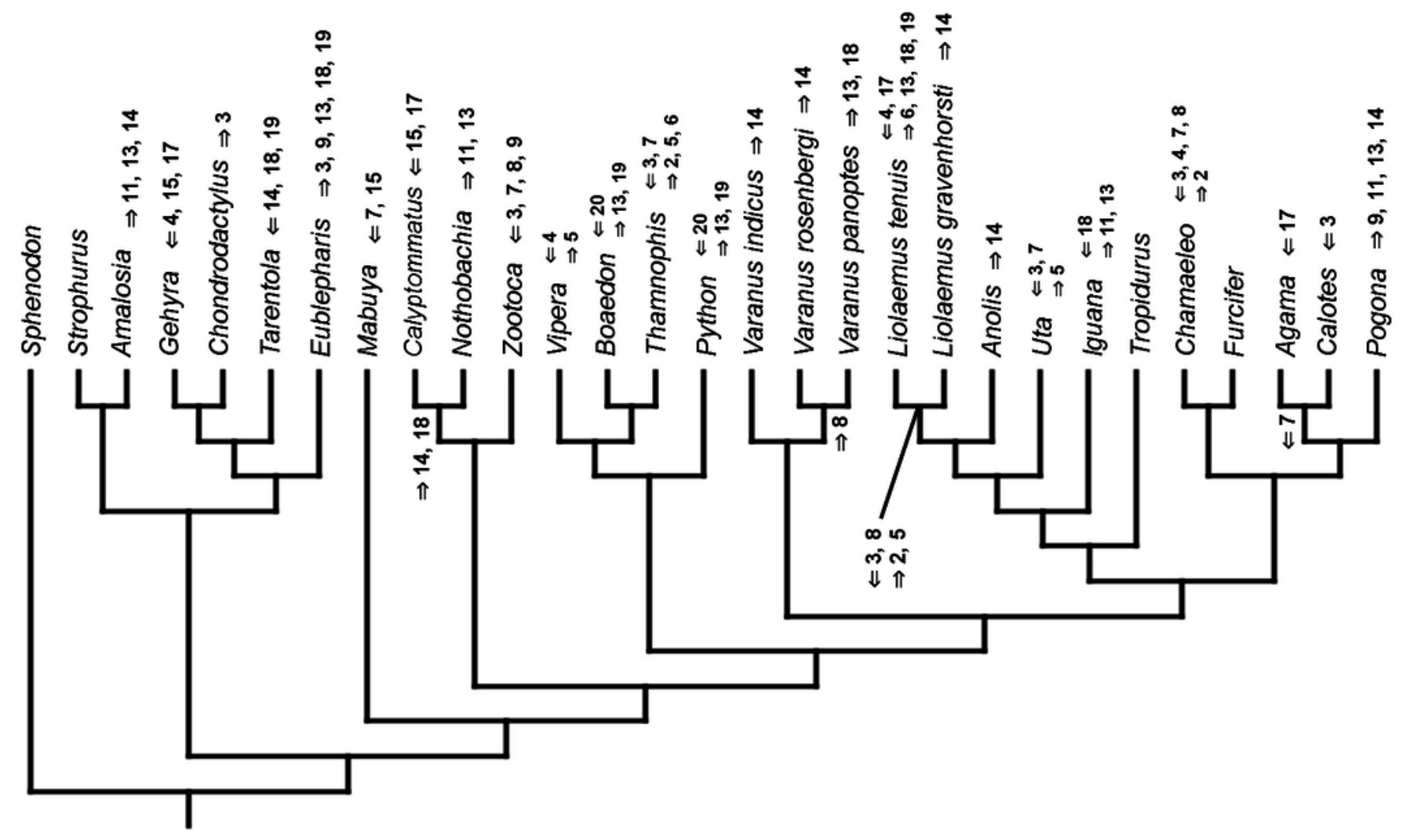


Figure 4

Heterochronic events in lepidosaur evolution.

Mapped onto molecular phylogeny, using continuous data, in relation to the ancestral squamate. Length of all branches equals 1 . Numbers refer to developmental events (Table 2). Down arrow denotes earlier development of a given structure, while up arrow represents later development.

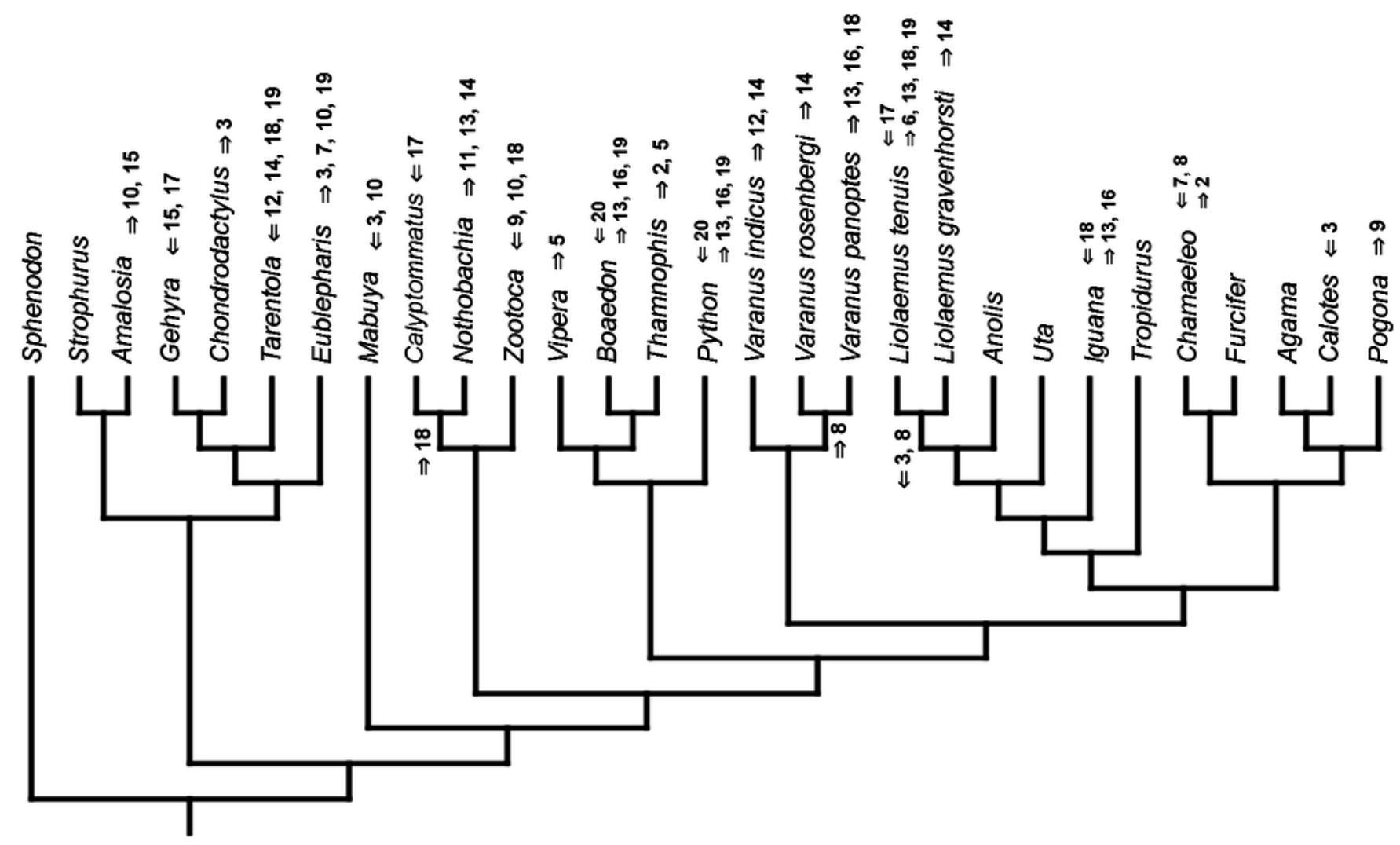


Figure 5

Heterochronic events in lepidosaur evolution.

Mapped onto molecular, stratigraphically calibrated phylogeny, using continuous data, in relation to the ancestral lepidosaur. Numbers refer to developmental events (Table 2). Down arrow denotes earlier development of a given structure, while up arrow represents later development.

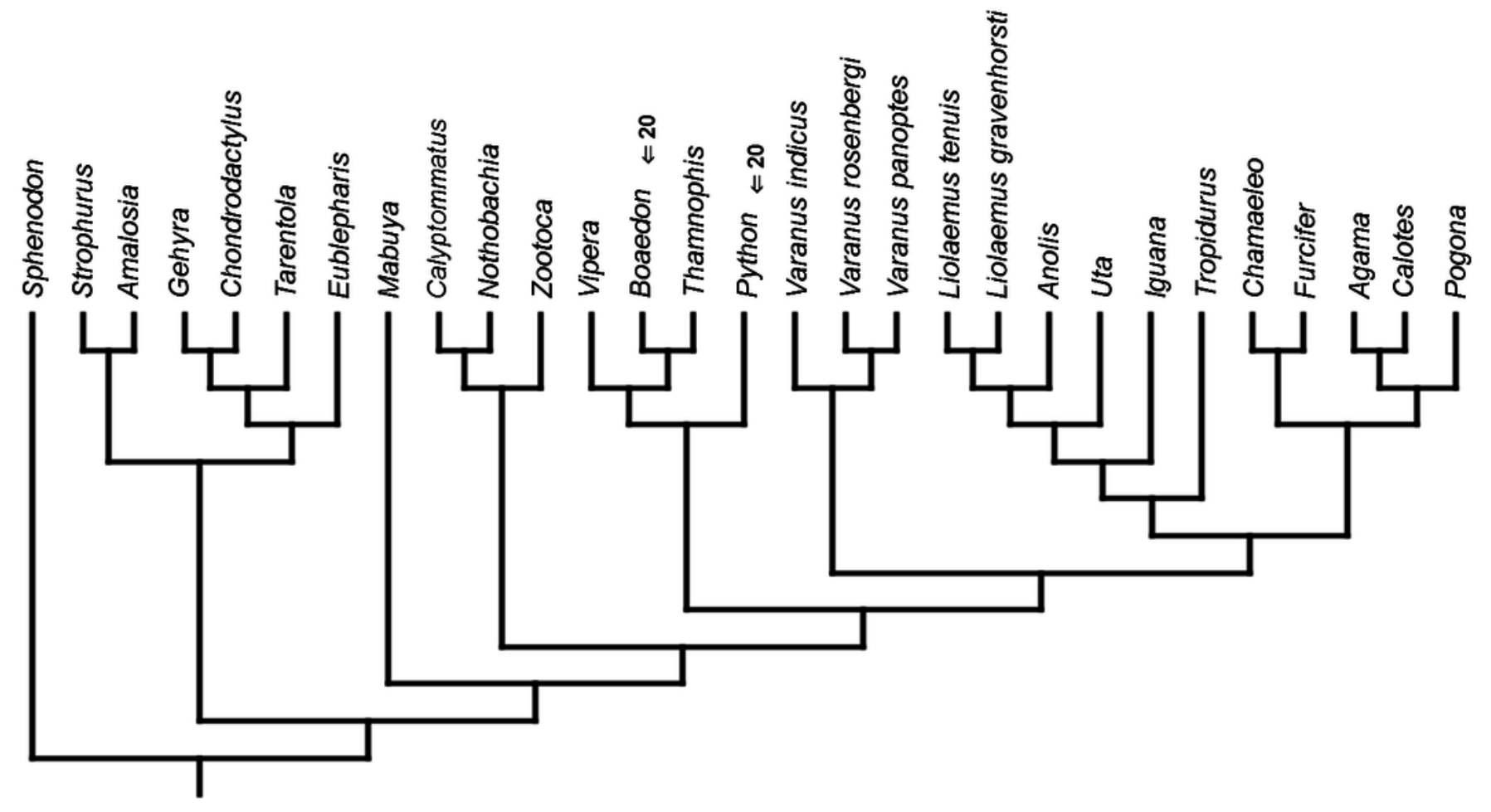


Figure 6

Heterochronic events in lepidosaur evolution.

Mapped onto molecular, stratigraphically calibrated phylogeny, using continuous data, in relation to the ancestral squamate. Numbers refer to developmental events (Table 2). Down arrow denotes earlier development of a given structure, while up arrow represents later development.

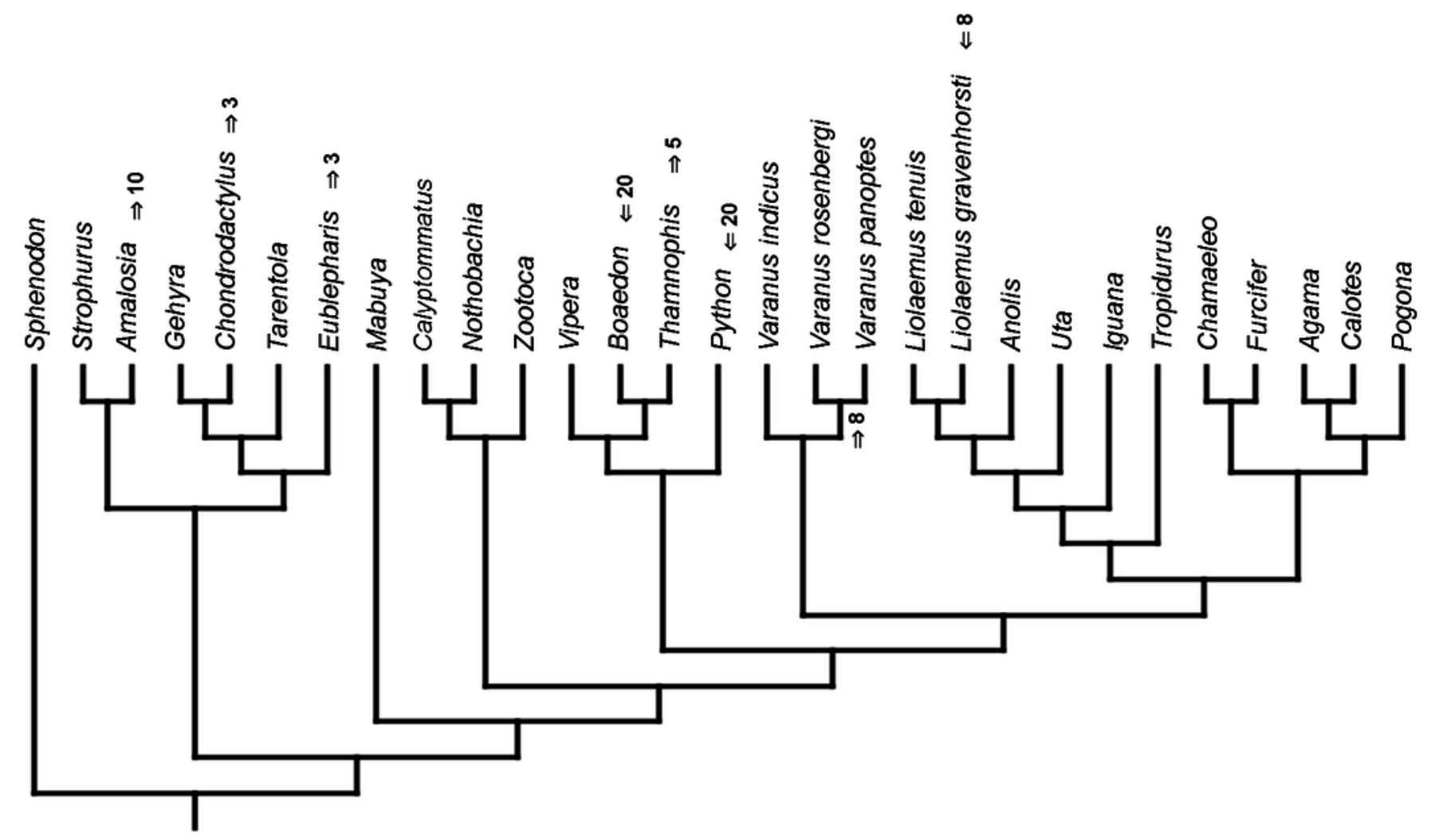


Figure 7

Heterochronic events in lepidosaur evolution.

Mapped onto morphological phylogeny, using continuous data, in relation to the ancestral lepidosaur. Length of all branches equals 1 . Numbers refer to developmental events (Table 2). Down arrow denotes earlier development of a given structure, while up arrow represents later development.

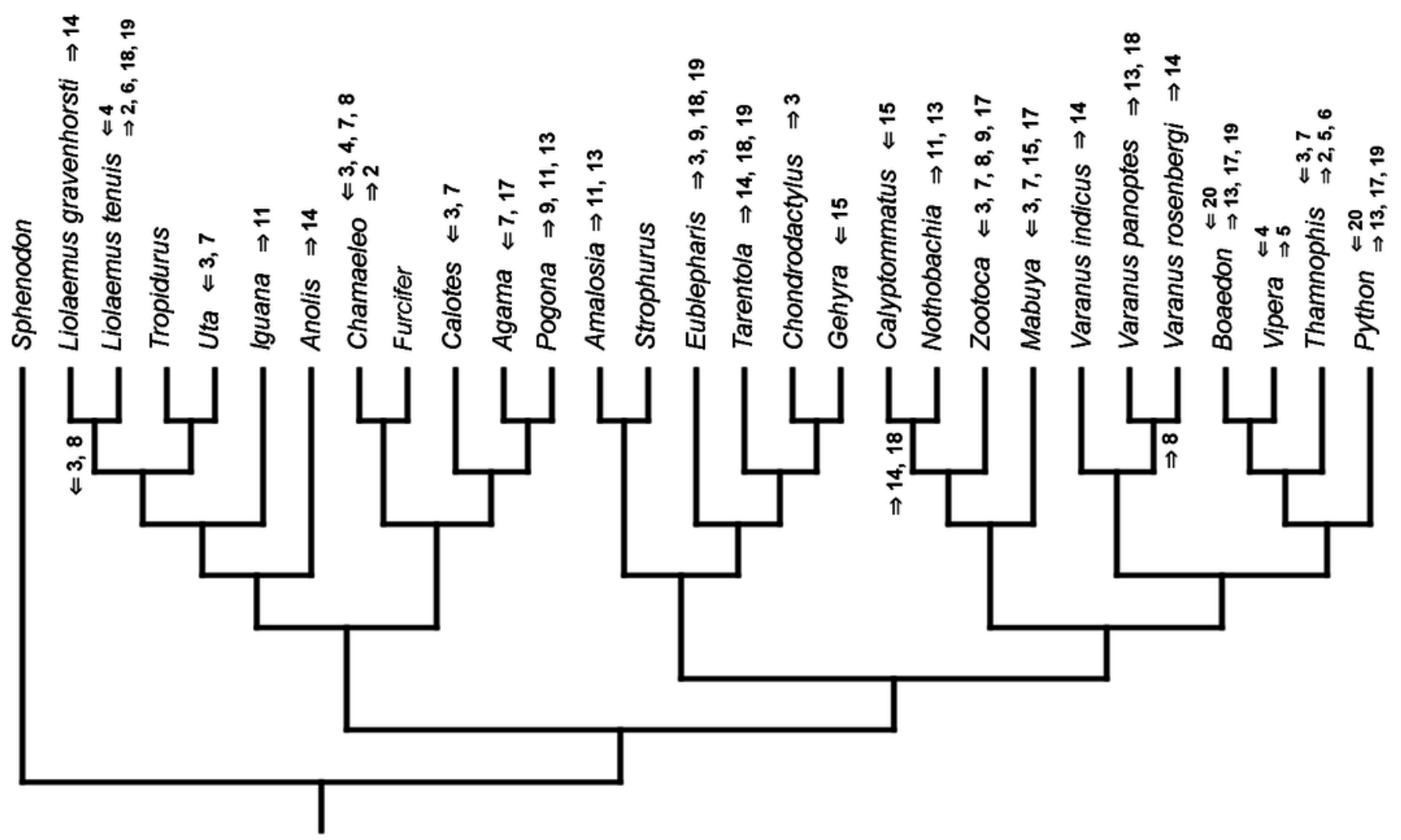


Figure 8

Heterochronic events in lepidosaur evolution.

Mapped onto morphological phylogeny, using continuous data, in relation to the ancestral squamate. Length of all branches equals 1 . Numbers refer to developmental events (Table 2). Down arrow denotes earlier development of a given structure, while up arrow represents later development.

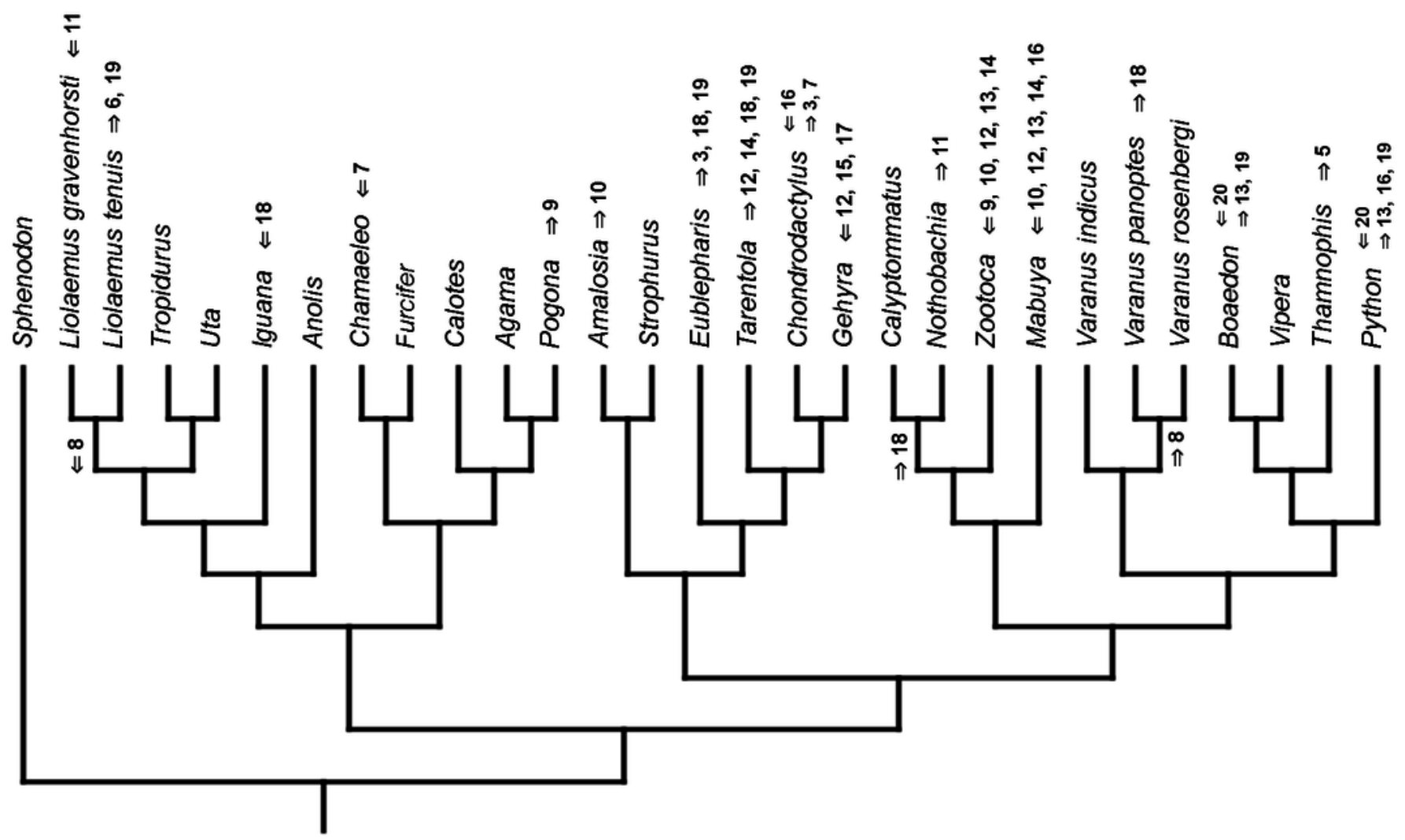


Figure 9

Heterochronic events in lepidosaur evolution.

Mapped onto morphological, stratigraphically calibrated phylogeny, using continuous data, in relation to the ancestral lepidosaur. Numbers refer to developmental events (Table 2). Down arrow denotes earlier development of a given structure, while up arrow represents later development.

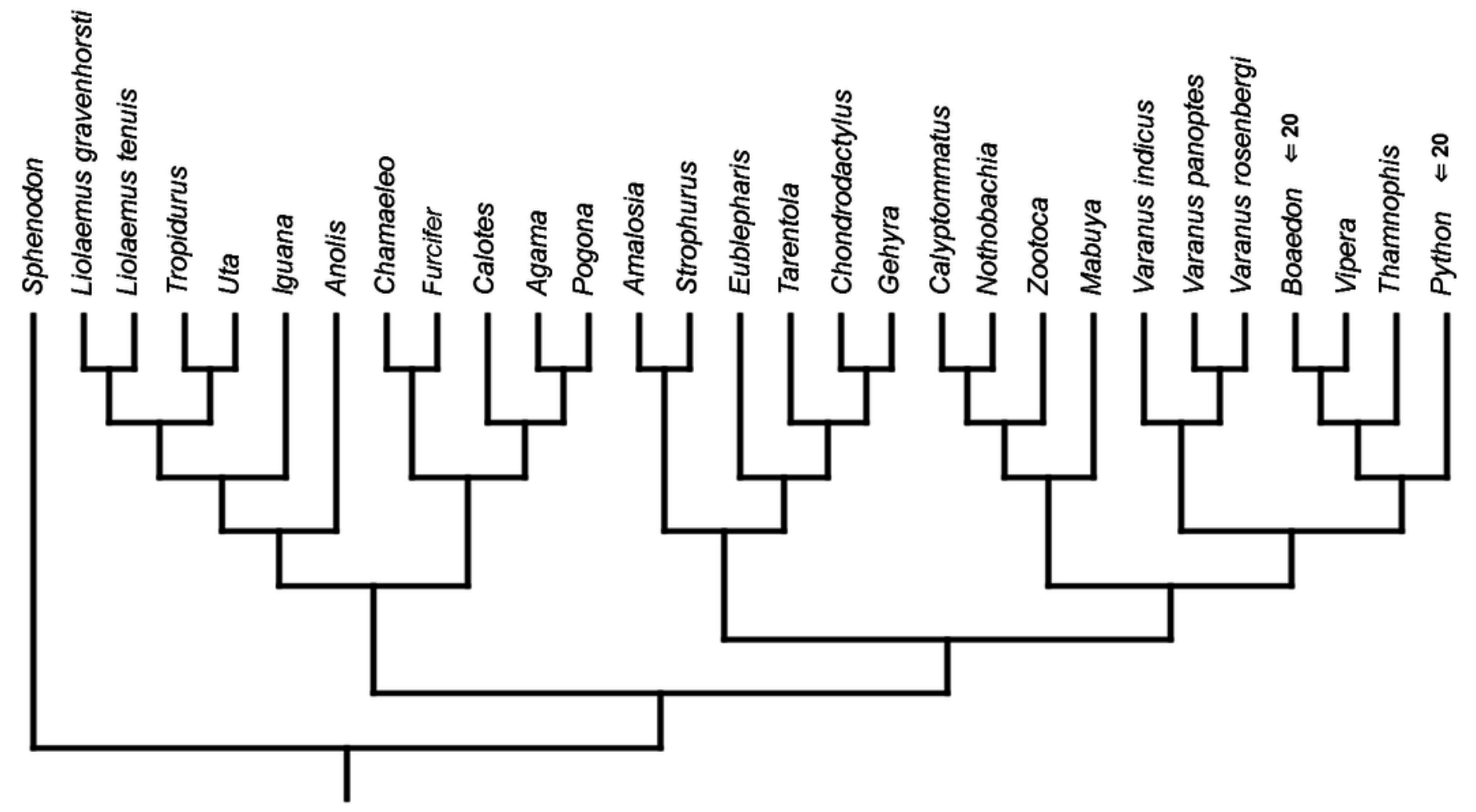


Figure 10

Heterochronic events in lepidosaur evolution.

Mapped onto morphological, stratigraphically calibrated phylogeny, using continuous data, in relation to the ancestral squamate. Numbers refer to developmental events (Table 2). Down arrow denotes earlier development of a given structure, while up arrow represents later development.

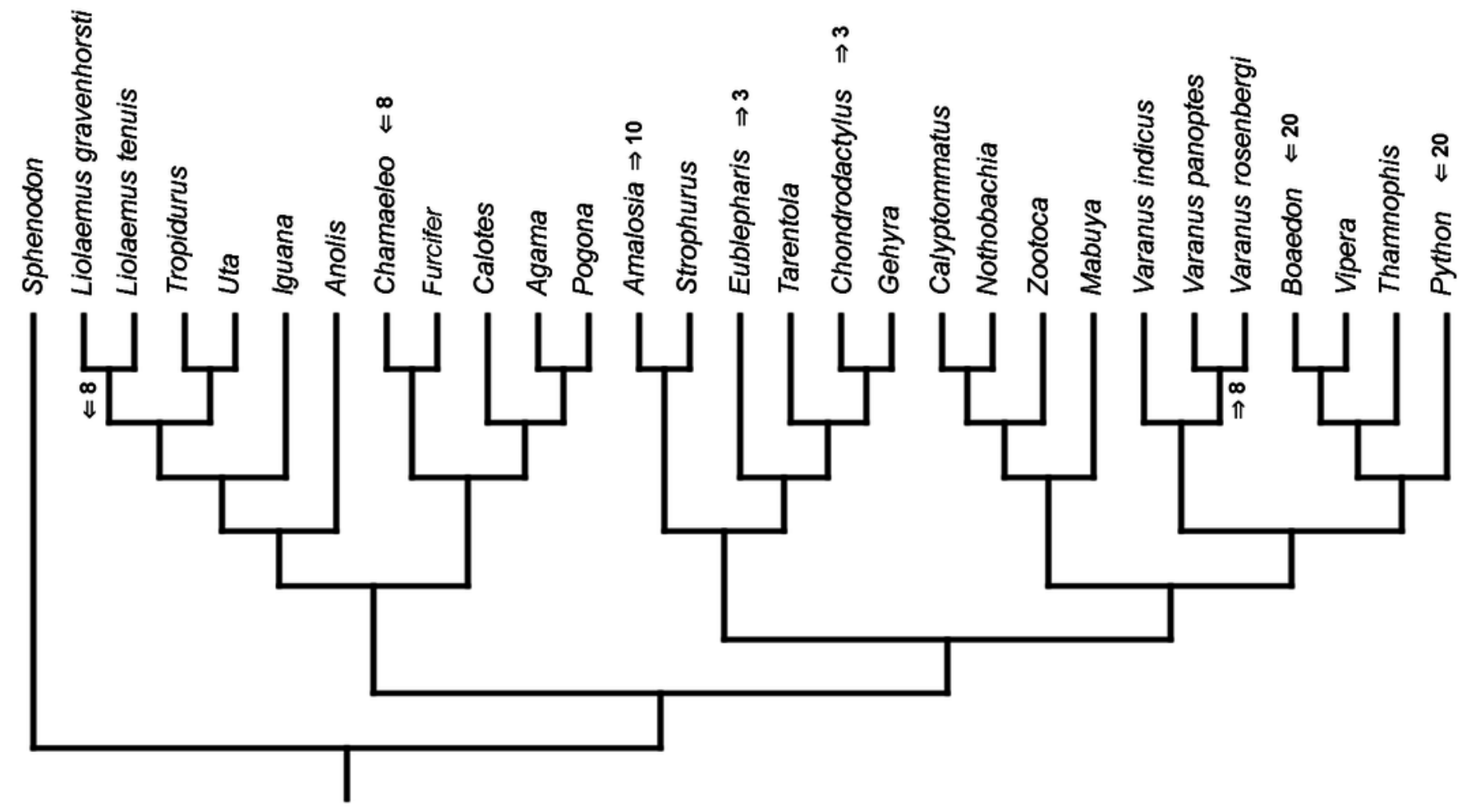


Figure 11

Heterochronic events in lepidosaur evolution.

Mapped onto molecular phylogeny, using unordered event-paired characters. Numbers refer to developmental events (Table 2). Down arrow denotes earlier development of a given structure, while up arrow represents later development.

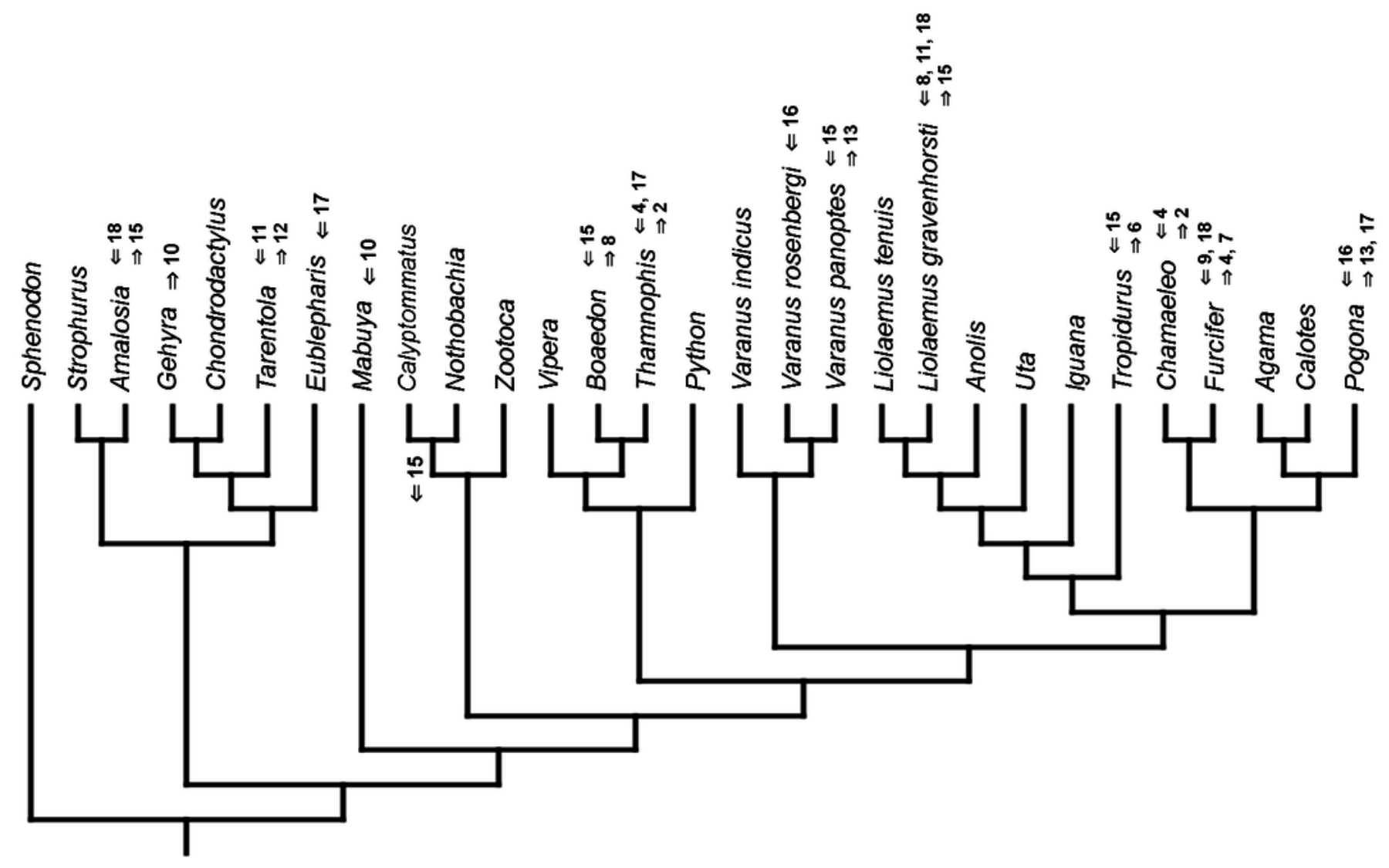


Figure 12

Heterochronic events in lepidosaur evolution.

Mapped onto molecular phylogeny, using ordered event-paired characters. Numbers refer to developmental events (Table 2). Down arrow denotes earlier development of a given structure, while up arrow represents later development.

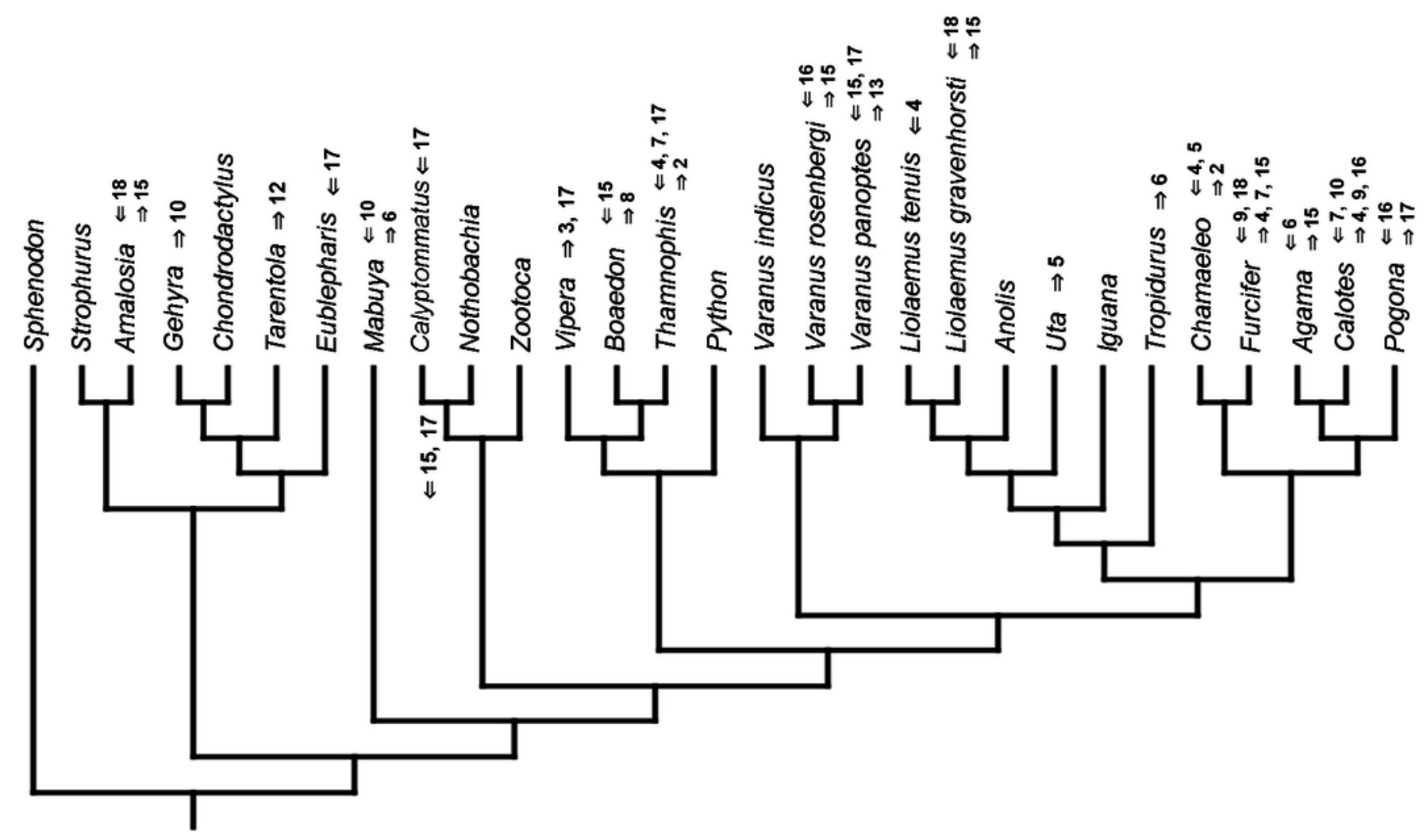


Figure 13

Heterochronic events in lepidosaur evolution.

Mapped onto morphological phylogeny, using unordered event-paired characters. Numbers refer to developmental events (Table 2). Down arrow denotes earlier development of a given structure, while up arrow represents later development.

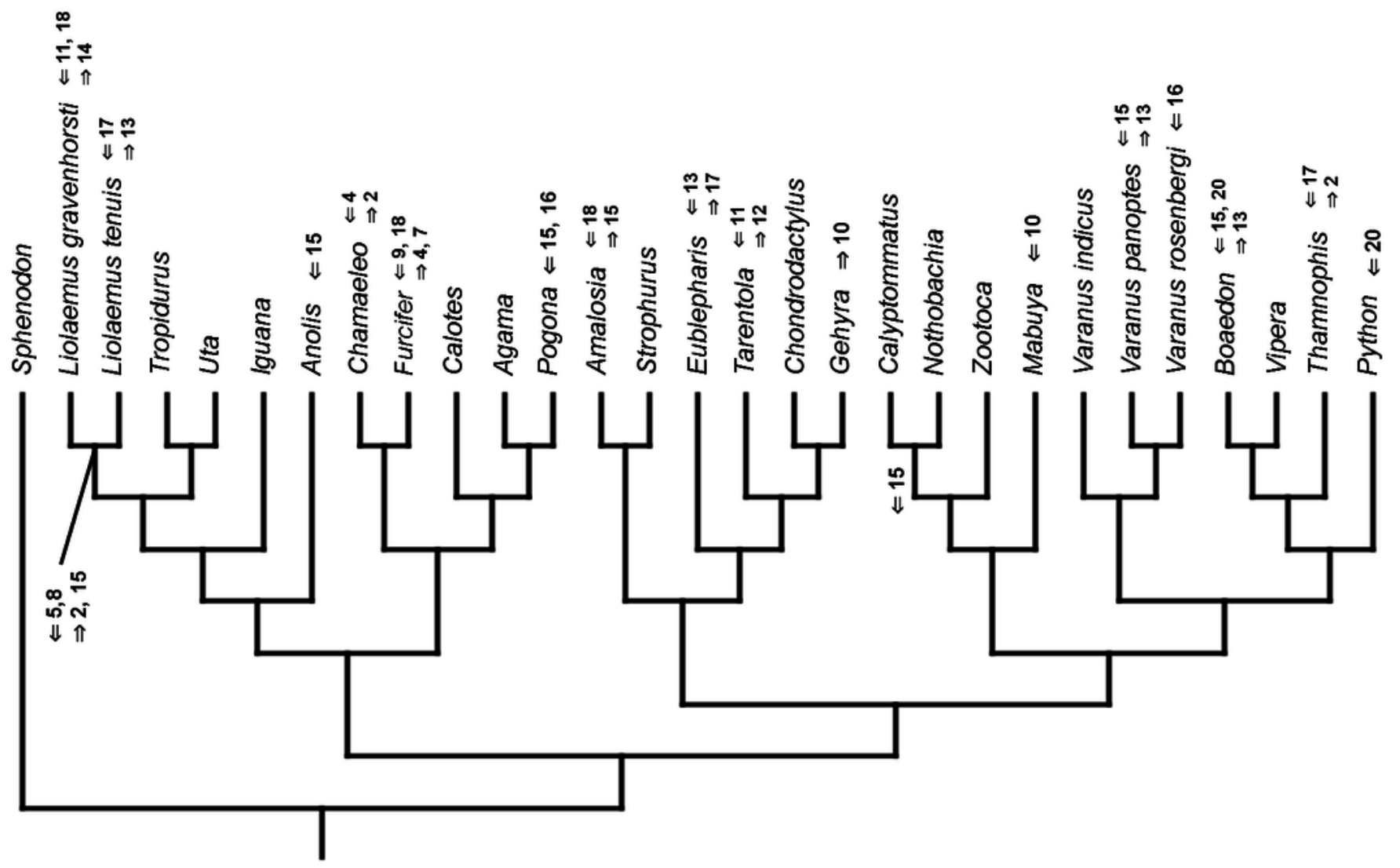


Figure 14

Heterochronic events in lepidosaur evolution.

Mapped onto morphological phylogeny, using ordered event-paired characters. Numbers refer to developmental events (Table 2). Down arrow denotes earlier development of a given structure, while up arrow represents later development.

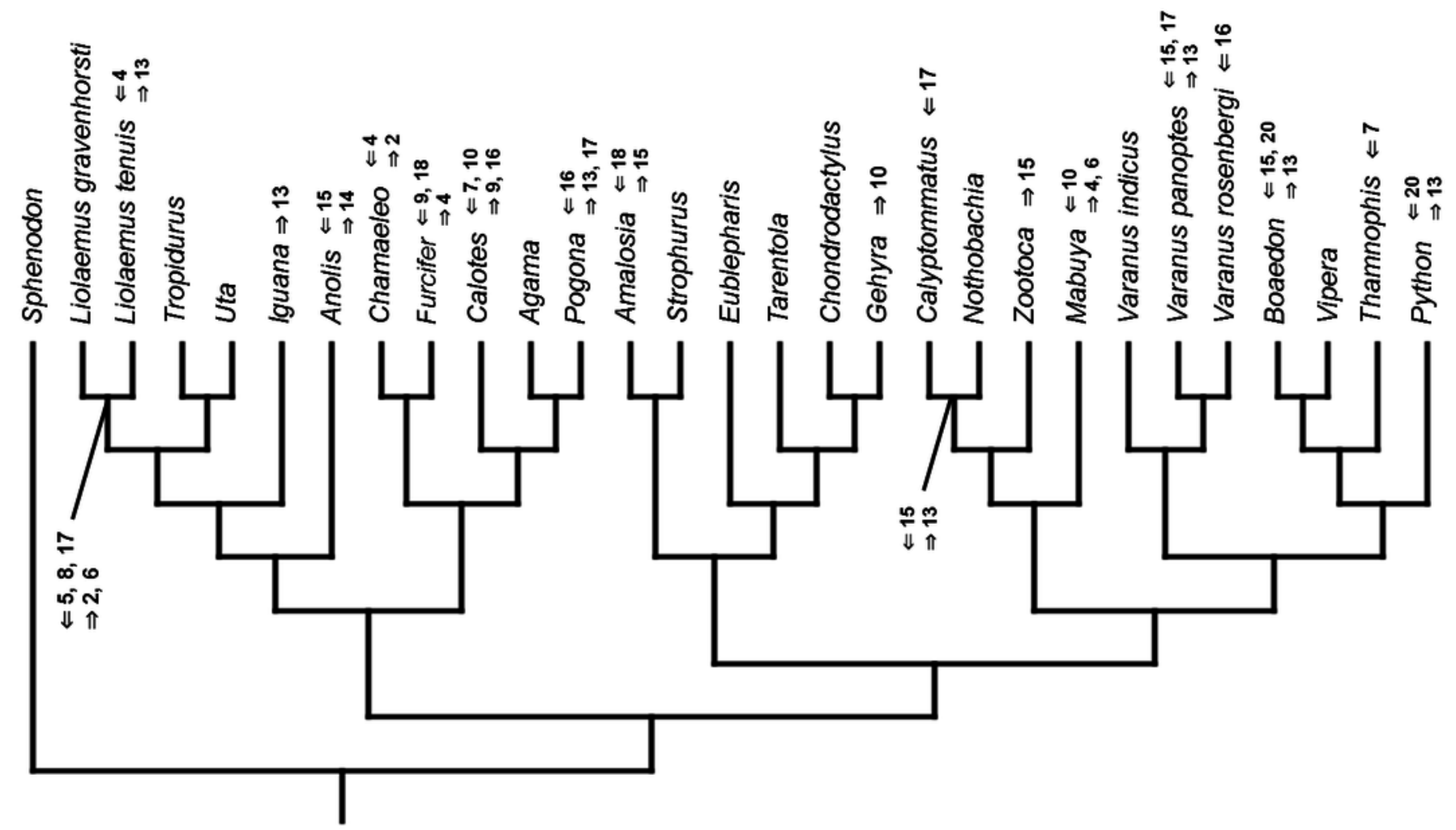




\section{Table $\mathbf{1}$ (on next page)}

Species included in this study, their taxonomic position and sources of information on their development. 


\begin{tabular}{|c|c|c|}
\hline Species & Higher taxon & Source \\
\hline $\begin{array}{l}\text { Sphenodon punctatus } \\
\text { (Gray, 1842) }\end{array}$ & $\begin{array}{l}\text { Rhynchocephalia: } \\
\text { Sphenodontidae }\end{array}$ & $\begin{array}{l}\text { Dendy, 1899; Moffat, 1985; } \\
\text { Sanger, Gredler \& Cohn, } 2015\end{array}$ \\
\hline $\begin{array}{l}\text { Amalosia lesueurii } \\
\text { (Duméril \& Bibron, 1836) }\end{array}$ & Gekkota: Diplodactylidae & $\begin{array}{l}\text { Andrews, Brandley \& Greene, } \\
2013\end{array}$ \\
\hline $\begin{array}{l}\text { Strophurus williamsi } \\
\text { (Kluge, 1963) }\end{array}$ & Gekkota: Diplodactylidae & $\begin{array}{l}\text { Andrews, Brandley \& Greene, } \\
2013\end{array}$ \\
\hline $\begin{array}{l}\text { Eublepharis macularius } \\
\text { (Blyth, 1854) }\end{array}$ & Gekkota: Eublepharidae & $\begin{array}{l}\text { Andrews, Brandley \& Greene, } \\
2013^{1}\end{array}$ \\
\hline $\begin{array}{l}\text { Tarentola annularis } \\
\text { (Geoffroy Saint-Hilaire, } \\
\text { 1827) }\end{array}$ & Gekkota: Phyllodactylidae & Khannoon, 2015 \\
\hline $\begin{array}{l}\text { Chondrodactylus turneri } \\
\text { (Gray, 1864) }\end{array}$ & Gekkota: Gekkonidae & $\begin{array}{l}\text { Andrews, Brandley \& Greene, } \\
2013\end{array}$ \\
\hline $\begin{array}{l}\text { Gehyra variegata (Duméril } \\
\& \text { Bibron, 1836) }\end{array}$ & Gekkota: Gekkonidae & $\begin{array}{l}\text { Andrews, Brandley \& Greene, } \\
2013\end{array}$ \\
\hline Mabuya sp. & Scincoidea: Scincidae & $\begin{array}{l}\text { Andrews, Brandley \& Greene, } \\
2013\end{array}$ \\
\hline $\begin{array}{l}\text { Calyptommatus } \\
\text { sinebrachiatus Rodrigues, } \\
1991\end{array}$ & $\begin{array}{l}\text { Lacertiformes: } \\
\text { Gymnophthalmidae }\end{array}$ & $\begin{array}{l}\text { Andrews, Brandley \& Greene, } \\
2013\end{array}$ \\
\hline $\begin{array}{l}\text { Nothobachia ablephara } \\
\text { Rodrigues, } 1984\end{array}$ & $\begin{array}{l}\text { Lacertiformes: } \\
\text { Gymnophthalmidae }\end{array}$ & $\begin{array}{l}\text { Andrews, Brandley \& Greene, } \\
2013\end{array}$ \\
\hline $\begin{array}{l}\text { Zootoca vivipara } \\
\text { (Lichtenstein, 1823) }\end{array}$ & Lacertiformes: Lacertidae & $\begin{array}{l}\text { Andrews, Brandley \& Greene, } \\
2013\end{array}$ \\
\hline $\begin{array}{l}\text { Python sebae (Gmelin, } \\
\text { 1789) }\end{array}$ & Serpentes: Pythonidae & Boughner et al., 2007 \\
\hline $\begin{array}{l}\text { Thamnophis sirtalis } \\
\text { (Linnaeus, 1758) }\end{array}$ & Serpentes: Colubridae & Andrews et al., 2013 \\
\hline $\begin{array}{l}\text { Boaedon fuliginosus (Boie, } \\
\text { 1827) }\end{array}$ & Serpentes: Lamprophiidae & $\begin{array}{l}\text { Boback, Dichter \& Mistry, } \\
2012\end{array}$ \\
\hline
\end{tabular}

${ }^{1}$ Wise, Vickaryous \& Russell (2009) presented slightly different developmental table for Eublepharis macularius but we used data from Andrews, Brandley \& Greene (2013), as they span the whole development. 


\begin{tabular}{|c|c|c|}
\hline $\begin{array}{l}\text { Vipera aspis (Linnaeus, } \\
1758 \text { ) }\end{array}$ & Serpentes: Viperidae & $\begin{array}{l}\text { Andrews, Brandley \& Greene, } \\
2013\end{array}$ \\
\hline $\begin{array}{l}\text { Varanus rosenbergi } \\
\text { Mertens, } 1957\end{array}$ & Anguimorpha: Varanidae & $\begin{array}{l}\text { Andrews, Brandley \& Greene, } \\
2013\end{array}$ \\
\hline $\begin{array}{l}\text { Varanus indicus (Daudin, } \\
1802 \text { ) }\end{array}$ & Anguimorpha: Varanidae & Gregorovicova et al., 2012 \\
\hline $\begin{array}{l}\text { Varanus panoptes Storr, } \\
1980\end{array}$ & Anguimorpha: Varanidae & $\begin{array}{l}\text { Werneburg, Polachowski \& } \\
\text { Hutchinson, } 2015\end{array}$ \\
\hline $\begin{array}{l}\text { Iguana iguana (Linnaeus, } \\
1758 \text { ) }\end{array}$ & $\begin{array}{l}\text { Iguania: Pleurodonta: } \\
\text { Iguanidae }\end{array}$ & Lima, 2015 \\
\hline $\begin{array}{l}\text { Uta stansburiana Baird \& } \\
\text { Girard, } 1852\end{array}$ & $\begin{array}{l}\text { Iguania: Pleurodonta: } \\
\text { Phrynosomatidae }\end{array}$ & $\begin{array}{l}\text { Andrews, Brandley \& Greene, } \\
2013\end{array}$ \\
\hline $\begin{array}{l}\text { Anolis sagrei Duméril \& } \\
\text { Bibron, } 1837\end{array}$ & $\begin{array}{l}\text { Iguania: Pleurodonta: } \\
\text { Dactyloidae }\end{array}$ & $\begin{array}{l}\text { Andrews, Brandley \& Greene, } \\
2013\end{array}$ \\
\hline $\begin{array}{l}\text { Liolaemus gravenhorsti } \\
\text { (Gray, } 1845)\end{array}$ & $\begin{array}{l}\text { Iguania: Pleurodonta: } \\
\text { Liolaemidae }\end{array}$ & $\begin{array}{l}\text { Andrews, Brandley \& Greene, } \\
2013\end{array}$ \\
\hline $\begin{array}{l}\text { Liolaemus tenuis (Duméril } \\
\text { \& Bibron, 1837) }\end{array}$ & $\begin{array}{l}\text { Iguania: Pleurodonta: } \\
\text { Liolaemidae }\end{array}$ & $\begin{array}{l}\text { Andrews, Brandley \& Greene, } \\
2013\end{array}$ \\
\hline $\begin{array}{l}\text { Tropidurus torquatus } \\
\text { (Wied-Neuwied, 1820) }\end{array}$ & $\begin{array}{l}\text { Iguania: Pleurodonta: } \\
\text { Tropiduridae }\end{array}$ & Py-Daniel et al., 2017 \\
\hline $\begin{array}{l}\text { Chamaeleo calyptratus } \\
\text { Duméril \& Duméril, } 1851\end{array}$ & $\begin{array}{l}\text { Iguania: Acrodonta: } \\
\text { Chamaeleonidae }\end{array}$ & $\begin{array}{l}\text { Andrews, Brandley \& Greene, } \\
2013\end{array}$ \\
\hline $\begin{array}{l}\text { Furcifer lateralis (Gray, } \\
\text { 1831) }\end{array}$ & $\begin{array}{l}\text { Iguania: Acrodonta: } \\
\text { Chamaeleonidae }\end{array}$ & $\begin{array}{l}\text { Andrews, Brandley \& Greene, } \\
2013\end{array}$ \\
\hline $\begin{array}{l}\text { Pogona vitticeps (Ahl, } \\
\text { 1926) }\end{array}$ & Iguania: Acrodonta: Agamidae & $\begin{array}{l}\text { Andrews, Brandley \& Greene, } \\
2013\end{array}$ \\
\hline $\begin{array}{l}\text { Calotes versicolor (Daudin, } \\
1802 \text { ) }\end{array}$ & Iguania: Acrodonta: Agamidae & $\begin{array}{l}\text { Andrews, Brandley \& Greene, } \\
2013\end{array}$ \\
\hline $\begin{array}{l}\text { Agama impalearis } \\
\text { Boettger, } 1874\end{array}$ & Iguania: Acrodonta: Agamidae & $\begin{array}{l}\text { Andrews, Brandley \& Greene, } \\
2013\end{array}$ \\
\hline
\end{tabular}




\section{Table 2 (on next page)}

Developmental events used in this study.

From Andrews, Brandley \& Greene (2013). 


\begin{tabular}{|c|c|}
\hline Number & Event \\
\hline 1 & Primary optic vesicle \\
\hline 2 & Otic placode \\
\hline 3 & $\begin{array}{l}\text { Allantois bud (small thick-walled out- } \\
\text { pouching) }\end{array}$ \\
\hline 4 & Torsion complete \\
\hline 5 & Secondary optic vesicle \\
\hline 6 & Hyomandibular slit \\
\hline 7 & Allantois vesicle (thin-walled bag) \\
\hline 8 & Choroid fissure open (horseshoe-shaped) \\
\hline 9 & Limb ridge \\
\hline 10 & $\begin{array}{l}\text { Allantois contacts chorion (allantois flattened } \\
\text { above embryo like umbrella) }\end{array}$ \\
\hline 11 & Maximum pharyngeal slits \\
\hline 12 & Limb Apical Ectodermal Ridge (AER) \\
\hline 13 & Hemipenal buds form on cloacal lip \\
\hline 14 & $\begin{array}{l}\text { Three-segmented limb (stylo-, zeugo-, } \\
\text { autopodium) }\end{array}$ \\
\hline 15 & Jaw initiated \\
\hline 16 & $\begin{array}{l}\text { Eyelid forms as a thin ribbon-like sheet of } \\
\text { tissue overlapping the eyeball }\end{array}$ \\
\hline 17 & Pharyngeal slits closed \\
\hline 18 & Digits differentiated in limb paddle \\
\hline 19 & Jaw complete; mandible meets tip of maxilla \\
\hline 20 & Scale anlagen visible \\
\hline
\end{tabular}




\section{Table 3 (on next page)}

Calibration points for the fossil time-calibrated analyses.

See "Material \& Methods" for details. 


\begin{tabular}{|c|c|c|c|}
\hline Taxon & Age & References & Notes \\
\hline Sauria & $256 \mathrm{Ma}$ & $\begin{array}{l}\text { Ezcurra, Scheyer \& } \\
\text { Butler, 2014; Ezcurra, } \\
2016\end{array}$ & \\
\hline Rhynchocephalia & $238 \mathrm{Ma}$ & Jones et al., 2013 & \\
\hline Iguania & $105 \mathrm{Ma}(99+3+3)$ & Daza et al., 2016 & $\begin{array}{l}\text { Much older, Jurassic, } \\
\text { fossils may represent } \\
\text { iguanians (e.g. Evans, } \\
\text { Prasad \& Manhas, } \\
\text { 2002) but their } \\
\text { systematic position is } \\
\text { ambiguous (e.g. Jones } \\
\text { et al., 2013). }\end{array}$ \\
\hline Acrodonta & $102 \mathrm{Ma}(99+3)$ & Daza et al., 2016 & \\
\hline Chamaeleonidae & $99 \mathrm{Ma}$ & Daza et al., 2016 & \\
\hline Agamidae & $99 \mathrm{Ma}$ & Daza et al., 2016 & \\
\hline Chamaeleo & $13 \mathrm{Ma}$ & Bolet \& Evans, 2014 & \\
\hline Tropiduridae & ca. $15 \mathrm{Ma}$ & $\begin{array}{l}\text { Conrad, Rieppel \& } \\
\text { Grande, } 2007\end{array}$ & \\
\hline Iguanidae & $56 \mathrm{Ma}$ & Nydam, 2013 & \\
\hline Anolis & $20 \mathrm{Ma}$ & Sherratt et al., 2015 & \\
\hline Gekkota & $150 \mathrm{Ma}$ & $\begin{array}{l}\text { Gauthier et al., 2012; } \\
\text { Caldwell et al., 2015 }\end{array}$ & $\begin{array}{l}\text { See also Daza, Bauer \& } \\
\text { Snively, } 2014\end{array}$ \\
\hline Gekkonidae & $15 \mathrm{Ma}$ & $\begin{array}{l}\text { Daza, Bauer \& } \\
\text { Snively, } 2014\end{array}$ & \\
\hline Diplodactylidae & $20 \mathrm{Ma}$ & $\begin{array}{l}\text { Daza, Bauer \& } \\
\text { Snively, } 2014\end{array}$ & \\
\hline Serpentes & $167 \mathrm{Ma}$ & Caldwell et al., 2015 & \\
\hline Pythonidae & $35 \mathrm{Ma}$ & Head, 2015 & \\
\hline Colubridae & $31 \mathrm{Ma}$ & Head, Mahlow \& & \\
\hline
\end{tabular}




\begin{tabular}{|c|c|c|c|}
\hline & & Müller, 2016 & \\
\hline Lamprophiidae & $17 \mathrm{Ma}$ & $\begin{array}{l}\text { Head, Mahlow \& } \\
\text { Müller, } 2016\end{array}$ & $\begin{array}{l}\text { Based on the elapid } \\
\text { Naja romani (Head, } \\
\text { Mahlow \& Müller, } \\
\text { 2016). }\end{array}$ \\
\hline Viperidae & $20 \mathrm{Ma}$ & $\begin{array}{l}\text { Head, Mahlow \& } \\
\text { Müller, } 2016\end{array}$ & \\
\hline Anguimorpha & $145 \mathrm{Ma}$ & $\begin{array}{l}\text { Head, 2015; Caldwell } \\
\text { et al., } 2015\end{array}$ & \\
\hline Lacertiformes & $99 \mathrm{Ma}$ & Daza et al., 2016 & \\
\hline Gymnophthalmidae & $66 \mathrm{Ma}$ & $\begin{array}{l}\text { Venczel \& Codrea, } \\
2016\end{array}$ & $\begin{array}{l}\text { Gymnophthalmid } \\
\text { fossils are currently } \\
\text { unknown (Nydam \& } \\
\text { Caldwell, 2015) but } \\
\text { teiids are universally } \\
\text { accepted as } \\
\text { gymnophthalmid sister } \\
\text { group, so the oldest } \\
\text { known teiid is used to } \\
\text { provide a calibration } \\
\text { point for } \\
\text { gymnophthalmids in } \\
\text { the analyses. }\end{array}$ \\
\hline Scincoidea & $150 \mathrm{Ma}$ & $\begin{array}{l}\text { Evans \& Chure, 1998; } \\
\text { Gauthier et al., } 2012\end{array}$ & $\begin{array}{l}\text { See also Conrad, } 2008 \\
\text { and Tałanda, } 2016- \\
\text { regardless of that, the } \\
\text { oldest known scincoids } \\
\text { seem to be Late } \\
\text { Jurassic in age. }\end{array}$ \\
\hline
\end{tabular}




\section{Table 4 (on next page)}

Event-paired developmental synapomorphies of higher-level squamate clades.

Asterisk denotes synapomorphies present only in analysis using ordered characters, while plus denotes synapomorphies present only in analysis employing unordered characters. 


\begin{tabular}{|c|c|}
\hline \multicolumn{2}{|l|}{ a) Molecular phylogeny } \\
\hline Clade & Synapomorphies \\
\hline Gekkota except Diplodactylidae & $\begin{array}{l}\text { (1) pharyngeal slits closed simultaneous with } \\
\text { three-segmented limb* }\end{array}$ \\
\hline Unidentata & $\begin{array}{l}\text { (1) secondary optic vesicle simultaneous with } \\
\text { allantois bud, (2) hyomandibular slit not earlier } \\
\text { than allantois bud }\end{array}$ \\
\hline Scincoidea (Mabuya) & $\begin{array}{l}\text { (1) hyomandibular slit later than secondary } \\
\text { optic vesicle, (2) allantois vesicle earlier than } \\
\text { torsion completion, (3) allantois contacts } \\
\text { chorion simultaneous with torsion completion, } \\
\text { (4) allantois contacts chorion simultaneous with } \\
\text { hyomandibular slit, (5) allantois contacts } \\
\text { chorion earlier than choroid fissure open, (6) } \\
\text { allantois contacts chorion earlier than limb } \\
\text { ridge*, (7) pharyngeal slits closed later than } \\
\text { eyelid forms as a thin ribbon-like sheet of tissue } \\
\text { overlapping the eyeball* }\end{array}$ \\
\hline Gymnophthalmidae & $\begin{array}{l}\text { (1) jaw initiated simultaneous with maximum } \\
\text { pharyngeal slits, (2) jaw initiated earlier than } \\
\text { hemipenal buds form on cloacal lips, (3) } \\
\text { pharyngeal slits closed simultaneous with } \\
\text { hemipenal buds form on cloacal lips*, }(4) \\
\text { pharyngeal slits closed simultaneous with three- } \\
\text { segmented limb*, (5) jaw completion } \\
\text { simultaneous with digits differentiated in the } \\
\text { limb paddle }\end{array}$ \\
\hline Toxicofera & $\begin{array}{l}\text { (1) secondary optic vesicle later than allantois } \\
\text { bud, (2) allantois vesicle simultaneous with } \\
\text { secondary optic vesicle* }\end{array}$ \\
\hline Serpentes & $\begin{array}{l}\text { (1) pharyngeal slits closed no later than } \\
\text { hemipenal buds form on cloacal lips*, }(2) \\
\text { pharyngeal slits closed earlier than eyelid form } \\
\text { as thin ribbon-like sheet of tissue* }\end{array}$ \\
\hline Thamnophis + Vipera & $\begin{array}{l}\text { (1) jaw initiated later than hemipenal buds form } \\
\text { on cloacal lips*, (2) eyelid form as thin ribbon- } \\
\text { like sheet of tissue simultaneous with jaw } \\
\text { initiated }\end{array}$ \\
\hline
\end{tabular}




\begin{tabular}{|c|c|}
\hline Varanus rosenbergi $+V$. panoptes & $\begin{array}{l}\text { (1) pharyngeal slits closed simultaneous with } \\
\text { three-segmented limb }\end{array}$ \\
\hline Iguania & (1) limb ridge later than choroid fissure open* \\
\hline Acrodonta & $\begin{array}{l}\text { (1) allantois vesicle simultaneous with torsion } \\
\text { completion+ }\end{array}$ \\
\hline Chamaeleonidae & $\begin{array}{l}\text { (1) allantois contacts chorion later than limb } \\
\text { ridge* }\end{array}$ \\
\hline Agama + Calotes & $\begin{array}{l}\text { (1) jaw initiated later than hemipenal buds form } \\
\text { on cloacal lips*, (2) jaw initiated later than } \\
\text { three-segmented limb*, (3) pharyngeal slits } \\
\text { closed simultaneous with jaw initiated* }\end{array}$ \\
\hline Pleurodonta excluding Tropidurus & $\begin{array}{l}\text { (1) pharyngeal slits closed simultaneous with } \\
\text { three-segmented limb* }\end{array}$ \\
\hline Liolaemus & $\begin{array}{l}\text { (1) jaw initiated simultaneous with three- } \\
\text { segmented limb+, (2) pharyngeal slits closed } \\
\text { earlier than jaw initiated }\end{array}$ \\
\hline \multicolumn{2}{|l|}{ b) Morphological phylogeny } \\
\hline Clade & Synapomorphies \\
\hline Iguania & (1) hyomandibular slit later than allantois bud* \\
\hline Pleurodonta & $\begin{array}{l}\text { (1) pharyngeal slits closed simultaneous with } \\
\text { three-segmented limb*, (2) pharyngeal slits } \\
\text { closed earlier than eyelid forms as thin ribbon- } \\
\text { like sheet of tissue* }\end{array}$ \\
\hline Liolaemus & $\begin{array}{l}\text { (1) allantois bud earlier than otic placode, }(2) \\
\text { secondary optic vesicle earlier than otic } \\
\text { placode, (3) secondary optic vesicle } \\
\text { simultaneous with allantois bud+, (4) } \\
\text { hyomandibular slit simultaneous with torsion } \\
\text { completion*, (5) hyomandibular slit later than } \\
\text { secondary optic vesicle*, (6) choroid fissure } \\
\text { open simultaneous with otic placode, }(7) \\
\text { choroid fissure open earlier than allantois } \\
\text { vesicle, (8) jaw initiated simultaneous with } \\
\text { three-segmented limb+, (9) pharyngeal slits } \\
\text { closed earlier than three-segmented limb*, (10) }\end{array}$ \\
\hline
\end{tabular}




\begin{tabular}{|c|c|}
\hline & pharyngeal slits closed earlier than jaw initiated \\
\hline Acrodonta & $\begin{array}{l}\text { (1) allantois vesicle simultaneous with torsion } \\
\text { completion+ }\end{array}$ \\
\hline Agama + Pogona & $\begin{array}{l}\text { (1) eyelid forms as thin ribbon-like sheet of } \\
\text { tissue simultaneous with jaw initiated* }\end{array}$ \\
\hline Chamaeleonidae & $\begin{array}{l}\text { (1) allantois contacts chorion later than } \operatorname{limb} \\
\text { ridge* }\end{array}$ \\
\hline Scleroglossa & $\begin{array}{l}\text { (1) torsion completion simultaneous with } \\
\text { allantois bud*, (2) hyomandibular slit } \\
\text { simultaneous with torsion completion }\end{array}$ \\
\hline Gekkota except Diplodactylidae & $\begin{array}{l}\text { (1) pharyngeal slits closed simultaneous with } \\
\text { three-segmented limb* }\end{array}$ \\
\hline Varanus rosenbergi $+V$. panoptes & $\begin{array}{l}\text { (1) pharyngeal slits closed simultaneous with } \\
\text { three-segmented limb }\end{array}$ \\
\hline Serpentes & $\begin{array}{l}\text { (1) pharyngeal slits closed earlier than eyelid } \\
\text { forms as a thin ribbon-like sheet of tissue* }\end{array}$ \\
\hline Scincomorpha & $\begin{array}{l}\text { (1) allantois bud simultaneous with otic } \\
\text { placode+, (2) secondary optic vesicle } \\
\text { simultaneous with otic placode }\end{array}$ \\
\hline Scincoidea (Mabuya) & $\begin{array}{l}\text { (1) torsion completion later than allantois bud*, } \\
\text { (2) secondary optic vesicle earlier than torsion } \\
\text { completion*, (3) hyomandibular slit later than } \\
\text { allantois bud*, (4) hyomandibular slit later than } \\
\text { secondary optic vesicle*, }(5) \text { allantois vesicle } \\
\text { earlier than torsion completion, }(6) \text { allantois } \\
\text { vesicle earlier than hyomandibular slit, (7) } \\
\text { allantois contacts chorion simultaneous with } \\
\text { torsion completion, }(8) \text { allantois contacts } \\
\text { chorion simultaneous with hyomandibular slit, } \\
(9) \text { allantois contacts chorion earlier than } \\
\text { choroid fissure open, }(10) \text { allantois contacts } \\
\text { chorion earlier than limb ridge, }(11) \text { jaw } \\
\text { initiated simultaneous with three-segmented } \\
\text { limb+ }\end{array}$ \\
\hline Gymnophthalmidae & $\begin{array}{l}\text { (1) jaw initiated simultaneous with maximum } \\
\text { pharyngeal slits, (2) jaw initiated earlier than }\end{array}$ \\
\hline
\end{tabular}


hemipenal buds form on cloacal lips, (3) jaw initiated earlier than three-segmented limb*, (4) pharyngeal slits closed simultaneous with hemipenal buds form on cloacal lips*, (5) pharyngeal slits closed simultaneous with threesegmented limb*, (6) jaw completion simultaneous with digits differentiated in limb paddle 